\title{
Regulations of Reversal of Senescence by PKC Isozymes in Response to 12-O-Tetradecanoylphorbol- 13-Acetate via Nuclear Translocation of pErk1/2
}

\author{
Yun Yeong Lee', Min Sook Ryu', Hong Seok Kim, Masami Suganuma ${ }^{2}, K y e$ Yong Song ${ }^{3}$, and \\ In Kyoung Lim,*
}

\begin{abstract}
The mechanism by which 12-0-tetradecanoylphorbol-13acetate (TPA) bypasses cellular senescence was investigated using human diploid fibroblast (HDF) cell replicative senescence as a model. Upon TPA treatment, protein kinase $C$ (PKC) $\alpha$ and PKC 1 exerted differential effects on the nuclear translocation of cytoplasmic pErk1/2, a protein which maintains senescence. PKC $\alpha$ accompanied pErk1/2 to the nucleus after freeing it from PEA-15p ${ }^{104}$ via PKCB1 and then was rapidly ubiquitinated and degraded within the nucleus. Mitogen-activated protein kinase docking motif and kinase activity of $P K C \alpha$ were both required for pErk1/2 transport to the nucleus. Repetitive exposure of mouse skin to TPA downregulated PKC $\alpha$ expression and increased epidermal and hair follicle cell proliferation. Thus, PKC $\alpha$ downregulation is accompanied by in vivo cell proliferation, as evidenced in 7, 12-dimethylbenz(a)anthracene (DMBA)-TPAmediated carcinogenesis. The ability of TPA to reverse senescence was further demonstrated in old HDF cells using RNA-sequencing analyses in which TPA-induced nuclear PKC $\alpha$ degradation freed nuclear pErk1/2 to induce cell proliferation and facilitated the recovery of mitochondrial energy metabolism. Our data indicate that TPAinduced senescence reversal and carcinogenesis promotion share the same molecular pathway. Loss of PKC $\alpha$ expression following TPA treatment reduces pErk1/2activated SP1 biding to the p21 WAF1 gene promoter, thus preventing senescence onset and overcoming G1/S cell cycle arrest in senescent cells.
\end{abstract}

\footnotetext{
${ }^{1}$ Department of Biochemistry and Molecular Biology, Ajou University School of Medicine, Suwon 443-380, Korea, ${ }^{2}$ Research Institute for Clinical Oncology, Saitama Cancer Center, Saitama, Japan, ${ }^{3}$ Department of Pathology, Chung-Ang University College of Medicine, Seoul 156-756, Korea, ${ }^{4}$ Present address: Department of Molecular Medicine, Inha University, College of Medicine, Incheon 22212, Korea

*Correspondence: iklim@ajou.ac.kr
}

Received 24 December, 2015; accepted 31 December, 2015; published online 24 February, 2016

Keywords: HDF, PKC $\alpha$, PKC $\beta 1$, SA-pErk1/2, tumor promotion

\section{INTRODUCTION}

A failure to induce epithelial cell senescence can significantly increase the risk of carcinogenic progression in both human and animals (Collado et al., 2005; Vernier et al., 2011). In fact, benign prostate hyperplasia, lung adenoma, intraductal neoplasia of the pancreas, skin papilloma, and other similar conditions can be successfully protected from cancer progression by oncogene-induced senescence, with cellular senescence functioning as a critical barrier that inhibits cancer progression. One of the characteristic features of senescent cells is the cytoplasmic sequestration of senescence-associated pErk1/2 (SApErk1/2), as opposed to G-actin accumulation in senescent cell nuclei (Lim et al., 2000). Potential mechanisms underlying the failure of pErk1/2 to translocate to the nucleus following growth factor stimulation include the inactivation of protein phosphatase 1 and 2A and MKP3/DUSP6 by reactive oxygen species (ROS) that accumulate in senescent human diploid fibroblasts (HDF) (Kim et al., 2003). However, when these senescent cells are exposed to 12-O-tetradecanoylphorbol-13-acetate (TPA) for $8 \mathrm{~h}$, the morphology of the old cells changes to resemble that of young cells, and there is a reversal in the expression of senescence markers, resulting in $\mathrm{G} 1 / \mathrm{S}$ progression and cell proliferation (Kim and Lim, 2009; Kwak et al., 2004; Lee et al., 2015).

Treating senescent cells with TPA triggers the rapid dissociation of SA-pErk1/2 from the phosphoprotein enriched in astrocytes (PEA-15) and induces $\mathrm{pErk1/2}$ translocation to the nucleus (Lee et al., 2015). In fact, TPA treatment or RNA interference-mediated knockdown of PKC $\alpha$ expression significantly induces the proliferation of old HDF cells (Kim and Lim, 2009). Collectively, these findings strongly support PKC $\alpha$ having a direct role in reversing senescent cell phenotypes. Indeed, PKCa is a mediator of G2/M cell cycle arrest and cellular senescence via the induction of p2 $1^{\text {WAF1 }}$ expression in the asynchronously growing non-small cell lung cancer cells (Oliva et al., 2008) and in primary cultures of HDF cells (Kim and Lim, 2009). Considering that TPA initially activates PKC isozymes and then downregulates their expression (Lu et al., 1998), the findings mentioned above strongly suggest that $\mathrm{PKC} \alpha$ downregulation might promote the reversal of primary culture HDF cell senescence. To the best of our knowledge, there are no published studies reporting that TPA reverses senescence phenotypes by downregulating PKC isozymes in both cultured cells and animal models. Moreover, we investigated the reversal of gene ex- 
pression profiles by performing RNA sequencing following TPA treatment and also validated mitochondrial respiration and metabolism.

The PKC protein family is divided into 4 subfamilies (conventional, novel, atypical, and distant) based on their cofactor requirements (Clemens et al., 1992; Nishizuka, 1995). Traditionally, PKC is known as a high affinity intracellular receptor for phorbol ester, a potent tumor promoter. Phorbol esters directly activate PKC, indicating that PKC is critically involved in growth control. Thus, it is widely accepted that PKC has a pivotal role in the regulation of cell proliferation and differentiation (Clemens et al., 1992; Nishizuka, 1992). Phorbol esters trigger longer PKC activation than physiological regulators: prolonged vs. transient PKC activation is an important distinction that may form the basis for phorbol ester-induced tumor promotion (Jaken, 1990; Nishizuka, 1992). Upon stimulation, PKC $\alpha$ translocates from the cytosol to particulate fractions (Buchner, 1995). We have observed that the stimulation of HDF cells with TPA activates PKC $\alpha, P K C \beta 1$ and PKC $\eta$ (Kim and Lim, 2009), consequently the isozymes moving from cytosol to particulate fractions in HDF cells. This suggested that PKC might have an important role in senescence, whereas the exact roles of PKC isozymes in reversal of senescence and carcinogenesis have not yet been reported.

The activity, but not amount, of PKCa is higher in the senescent cells than in the young cells due to the accumulation of ROS, which stimulates SA-pErk1/2 and p2 $1^{\text {WAF1 }}$ transcription to help maintain senescence (Kim and Lim, 2009). Indeed, the treatment of HepG2 cells with TPA induces PKC $\alpha$ activation along with Erk1/2 signaling and growth inhibition (Wen-Sheng and Jun-Ming, 2005), implying that all factors regulating the mitogen-activated protein kinase (MAPK) signaling pathway are involved in the activation of PKC $\alpha$ in response to TPA (Alexandropoulos et al., 1993; Thomas et al., 1992). To achieve their effects, these signals have to reach the nucleus after activation; thus, Buchner (1995) suggested several possibilities for PKC-mediated signal transduction into the nucleus. On the other hand, signal transduction to the nucleus might also be accomplished by the nuclear translocation of PKC itself via a nuclear pore complex following activation in the cytoplasm and phorbol ester-stimulated Erk1 via protein-tyrosine/threonine kinase activation (Alessandrini et al., 1992).

The MAPK pathway regulates various physiologic functions, including cell proliferation, differentiation, and apoptosis (Chang and Karin, 2001; Pearson et al., 2001). In addition, ERK1 and ERK2, the terminal elements of this pathway, activate transcription factors (e.g., c-fos and Elk-1) in the nucleus upon their phosphorylation (Cruzalegui et al., 1999; Kazi and Soh, 2008). Therefore, pErk1/2 must translocate to the nucleus to activate downstream transcription factors in response to various stimuli, and a significant fraction ( $\geq 50 \%$ ) of $p E r k 1 / 2$ can be found in the nucleus within 10 min of stimulation with a growth factor and phorbol ester (Chen et al., 1992). The redistribution of $p E r k 1 / 2$ is regulated by its interaction with various proteins, including PEA-15 (Camps et al., 1998; Menice et al., 1997), which directly binds to Erk1/2 or pErk1/2 in vitro and in vivo (Araujo et al., 1993). Through this activity, PEA-15 indirectly contributes to the maintenance of cellular senescence, and its phosphorylation at $\mathrm{S}^{104}$ blocks its interaction with ERK (Krueger et al., 2005; Renganathan et al., 2005; Vaidyanathan et al., 2007). Through this activity, PEA-15 indirectly contributes to the maintenance of cellular senescence, and its phosphorylation at $S^{104}$ blocks its interaction with ERK. The above findings prompted us to explore how PKC isozymes and Erk1/2 interact to reverse senes- cence and promote carcinogenesis following TPA stimulation, with a focus on the differential activities of PKC $\alpha$ and PKC $\beta 1$. In addition, we investigated changes in the kinetics of PKC degradation during the early and late stages of reverse senescence in response to TPA. Our results show that PKC $\beta 1$ activity dissociates SA-pErk1/2 from PEA-15 and that PKC $\alpha$ functions as a carrier protein facilitating $\mathrm{pErk} 1 / 2$ translocation to senescent cell nuclei. The PKC $\alpha$ kinase domain and its MAPK docking motif were both required for nuclear translocation of SApErk1/2 in senescent cells. PKC $\alpha$ degradation within the nucleus occurred in conjunction with pErk1/2 inactivation, resulting in the proliferation of senescent HDF cells and CD1 mouse epidermal cells following the application of skin carcinogenesisinducing 7, 12-dimethylbenz(a)anthracene (DMBA)/TPA. These data imply that the molecular changes observed during tumor promotion are similar to the changes that occur upon senescence reversal following TPA stimulation.

\section{MATERIALS AND METHODS}

TPA and 7, 12-dimethylbenz[a]anthracene (DMBA) were purchased from Sigma (USA). Antibodies to $p E r k 1 / 2$, Erk1/2, PEA$15 \mathrm{pS}^{104}$ and PEA-15 were from Cell Signaling (USA); against $\mathrm{PKC} \beta 1$, Lamin B1, HA, ubiquitin (Ub) and a-tubulin were from Santa Cruz Biotechnology (USA); against PKC $\alpha$ from Novus Biologicals (Littleton, USA). Active forms of PKC $\alpha$ and PKC $\beta 1$, and PKC activators were purchased from Millipore (USA).

\section{Cell culture}

HDF cells were isolated in our laboratory from the foreskin of 1-4 years old boys and maintained in Dulbecco's modified Eagle's medium (DMEM, Invitrogen/GIBCO, USA) supplemented with $10 \%$ fetal bovine serum (FBS; Invitrogen). The cell line preparation was undertaken with the understanding and written consent of each subject, and the study methodologies conformed to the standards set by the Declaration of Helsinki. The obtained normal tissues were used after informed written consent according to the regulation of Institutional Review Board at the Ajou University Hospital. The subjects were not injured or abused during the study. All tissues were immediately used after resection and the prepared cells were maintained more than 6 months in order to make the replicatively senescent cells (doubling time over 14 days). To perform the planned experiments, the primary cultures of various passages stored at the liquid nitrogen tanks were revived before use for the experiments. To examine the primary cultures, karyotyping was performed with HDF young and HDF old cells and the chromosome arrangements were analyzed under the microscope (Olympus, BX50F-3) with Cytovision 3.92 (Applied Imaging, England). Number of population doublings and their doubling times were calculated by the published equations (Kim and Lim, 2009). HDF young cells, mid-old and old cells used in this study represent doubling time of around $26 \mathrm{~h}$, around 4-10 days and over 14 days, respectively. Huh7 cells were obtained from Japanese Collection of Research Bioresources Cell Bank (Japan) and cultured in DMEM supplemented with 10\% FBS. All cells used in this study were maintained in $5 \% \mathrm{CO} 2$ incubator at $37^{\circ} \mathrm{C}$.

\section{Cell fractionation}

Cells were harvested, washed with ice cold 1x PBS, and then lysed in $250 \mu$ of TD buffer [25 mM Tris base ( $\mathrm{pH} 8.0), 2.0 \mathrm{mM}$ $\mathrm{MgCl} 2,0.25 \% \mathrm{v} / \mathrm{v}$ Nonident P40, $0.5 \mathrm{mM}$ DTT, $1.0 \mu \mathrm{g} / \mathrm{ml}$ leupeptin, $100 \mu \mathrm{g} / \mathrm{ml}$ PMSF, $1.0 \mathrm{mM} \mathrm{Na} 3 \mathrm{VO} 4,1.0 \mathrm{mM} \mathrm{NaF}$ ] for $5 \mathrm{~min}$ at room temperature (RT). The lysates were centrifuged 
at $12,000 \times g$ for $5 \mathrm{~min}$ and the supernatant was collected as cytoplasmic fraction. The pellets were suspended in $125 \mu \mathrm{l}$ of BL buffer [10 mM Tris (pH 8.0), 0.4 M LiCl, 0.5 mM DTT, 1.0 $\mu \mathrm{g} / \mathrm{ml}$ leupeptin, $100 \mu \mathrm{g} / \mathrm{ml}$ PMSF, $1.0 \mathrm{mM}$ Na3VO4, $1.0 \mathrm{mM}$ $\mathrm{NaF}$ ] for $5 \mathrm{~min}$, and followed by centrifugation at $12,000 \times g$ for $20 \mathrm{~min}$ to remove cell debris, and used as nuclear fraction. Protein concentration of each sample was assessed by BioRad protein assay kit (USA).

\section{Immunoblot (IB) analysis}

Cells were solubilized in RIPA buffer [50 mM Tris/ $\mathrm{HCl}(\mathrm{pH} 7.5)$, $150 \mathrm{mM} \mathrm{NaCl}, 1.0 \%$ Nonidet P40, 0.1\% SDS, 0.5\% deoxycholic acid, $1.0 \mu \mathrm{g} / \mathrm{ml}$ leupeptin, $100 \mu \mathrm{g} / \mathrm{ml}$ PMSF, $1.0 \mathrm{mM}$ $\mathrm{Na}$ VO4, 1.0 mM NaF], cleared by centrifugation at $12,000 \times g$ for $10 \mathrm{~min}$ at $4^{\circ} \mathrm{C}$, and then $40 \mu \mathrm{g}$ of the lysates (per lane) were resolved on $10-15 \%$ SDS-PAGE in $25 \mathrm{mM}$ Tris/glycine buffer. The protein bands were transferred to polyvinylidene fluoride membrane and then treated with $5 \%$ non-fat skim milk in PBS containing $0.05 \%$ Tween 20 (PBST) for $1 \mathrm{~h}$ before incubation with antibodies overnight at $4^{\circ} \mathrm{C}$, and then incubated with horseradish peroxidase-conjugated secondary antibodies for 1 h. ECL (Amersham Biosciences, UK) was employed to visualize the bands.

\section{Immunoprecipitation (IP)}

Immunoprecipitation was performed with cell lysates $(\sim 1.0 \mathrm{mg}$ protein) in the modified RIPA buffer (without $0.1 \%$ SDS from RIPA) by the standard method. Whole cell lysates were precleared with protein G-agarose beads (Invitrogen) for $1 \mathrm{~h}$ at $4^{\circ} \mathrm{C}$ before precipitation for $4 \mathrm{~h}$ with primary antibodies at $4^{\circ} \mathrm{C}$. The immunoprecipitates were washed 5 times with IP buffer, and then subjected to IB analysis.

\section{Immunocytochemistry (ICC)}

Cells on cover slips $(18 \mathrm{~mm} \times 18 \mathrm{~mm})$ in 6 -well plates were washed twice with $1 \times$ PBS before fixation with $4 \%$ paraformaldehyde for $15 \mathrm{~min}$, permeabilized with $0.05 \%$ Triton X-100 (diluted in 1xPBS) for $15 \mathrm{~min}$, and then subjected to blocking with $3 \%$ bovine serum albumin (BSA) in $0.05 \%$ Triton $\mathrm{X}-100$ at $4^{\circ} \mathrm{C}$ for $2 \mathrm{~h}$. The cells were incubated overnight with primary antibody at $4^{\circ} \mathrm{C}$, with secondary antibody at $4^{\circ} \mathrm{C}$ for $2 \mathrm{~h}$, and then stained with $4 \%$ 6-diamidino-2-phenylindole (DAPI, $1.0 \mu \mathrm{g} / \mathrm{ml}$ ) for $5 \mathrm{~min}$ at RT before mounting with Mowiol medium (Hoeschst Celanese, USA) containing antifade 1,4-diazabicyclo [2,2,2]octane (Aldrich, USA). Expressions of pErk1/2, PKC $\alpha$, PKC mutants, PKC $\beta 1$ and ubiquitin (Ub) were detected using monoclonal or polyclonal primary antibodies along with Alexa 488 or Alexa 594 conjugated secondary antibodies. Data acquisition under fluorescence microscope was done by AxioVision with software package (Carl Zeiss Microlmaging $\mathrm{GmbH}$, Germany), and Images were analyzed by Eclipse Ti (Nikon, Japan) or A1 confocal microscope (Japan).

\section{Two stage skin carcinogenesis}

CD-1 male mice (7 week old) purchased from ORIENT BIO Inc (Korea) were acclimatized in the animal house of Ajou University animal facilities for 3 weeks before shaving the hair. TPA ( 5 $\mu \mathrm{g} / 200 \mu \mathrm{l}$ acetone) was topically applied on the back skin of the mice for 2 weeks (twice/week) with or without DMBA (100 $\mu \mathrm{g} / 200 \mu \mathrm{l}$ acetone) initiation 1 week before TPA treatment according to the protocol (Abel et al., 2009). Mice were sacrificed on 3 days of the TPA final treatment, and then the back skin was surgically removed and embedded in the O.C.T. compound (Sakura Finetek, USA) for frozen section or fixed in $10 \%$ formalin solution for paraffin embedding. Paraffin sections were cut (4 $\mu \mathrm{m}$ thickness), and processed for hematoxylin-eosin (H\&E) staining according to the described method (Devanand et al., 2014). All of the animal procedures were followed by Ajou University Institutional Review Board.

\section{Immunofluorescence (IF) study}

Frozen sections (10 $\mu \mathrm{m}$ thickness) fixed at RT for $15 \mathrm{~min}$ were incubated in $0.3 \% \mathrm{H} 2 \mathrm{O} 2$ in PBS for 10 min to block endogenous peroxidase activity, and then incubated in $0.05 \%$ Triton X100 containing $10 \%$ BSA for 40 min at RT before washing 3 times with $1 \mathrm{x}$ PBS. The rest of the procedures followed the method described under the above immunocytochemistry. $\mathrm{PKC} \alpha$ was detected using monoclonal antibody along with Alexa 488 conjugated goat-anti mouse $\lg$ as a secondary antibody.

\section{GST-pull down and in vitro kinase-IB analyses}

Recombinant GST-PEA-15 proteins were expressed in E.coli strain BL21 (DE3) and purified to homogeneity using glutathione agarose 4B beads (Incospharm, Korea). The GST- or GST-PEA-15-conjugated glutathione agarose 4B beads were washed twice with kinase buffer [50 mM HEPES, ( $\mathrm{pH} 7.5), 10$ $\mathrm{mM} \mathrm{MgCl}$, $1 \mathrm{mM}$ DTT, $2.5 \mathrm{mM}$ EGTA, protease inhibitors and phosphatase inhibitors], and then in vitro kinase assay was initiated with 100-200 ng of GST-PEA-15, $400 \mu \mathrm{M}$ ATP and 0.1 $\mu \mathrm{g}$ PKC $\beta 1$ enzyme (Millipore, USA) in $10 \mu \mathrm{l}$ of the buffer. Reaction mixtures were incubated at $30^{\circ} \mathrm{C}$ for $30 \mathrm{~min}$, and then terminated by adding SDS sample buffer with subsequent boiling for $5 \mathrm{~min}$. Enzyme activity was analyzed by SDS-PAGE and

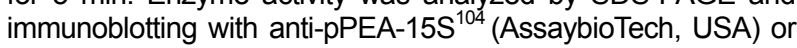
anti-GST (Santa Cruz) antibodies. GST was employed as a control substrate of the assay.

\section{siRNA transfection}

siRNAs against PKCa (siPKC $\alpha$ ) were purchased from Santa Cruz Biotechnology, siPKC $\beta 1$ (Sense - 5' CAUUACAUUUCAAACUUUAUU 3', Antisense - 5' UAAAGUUUGAAAUGUAAUGUU 3') from Genolution Pharmaceuticals (Asan Institute for Life Sciences, Korea), and control siRNAs (siControl) were from DHARMACON (USA). HDF old cells cultured on a cover slip $(18 \mathrm{~mm} \times 18 \mathrm{~mm})$ in 6-well plates were transfected with siRNAs and oligofectamine (Invitrogen) for 4-6 h. After $48 \mathrm{~h}$, the cells were treated with either DMSO $(0.01 \%)$ or TPA $(50 \mathrm{ng} / \mathrm{ml})$ for $30 \mathrm{~min}$ before subjected to ICC or IB analyses.

\section{Plasmid transfection}

Huh7 cells cultured in 6 -well plates $\left(5 \times 10^{4}\right.$ cells/well) or $100 \mathrm{~mm}$ dishes $\left(2 \times 10^{5}\right.$ cells/well) were transiently transfected with 2 or $10 \mu \mathrm{g}$ of pHACE (vector), wt-PKC $\alpha$ or mt-PKC $\alpha\left(\mathrm{R}^{159,161} \mathrm{G}\right)$ using Fugene (Promega, USA), and then subjected to ICC or cell fractionations into nuclei and cytoplasm in $48 \mathrm{~h}$ of transfection.

\section{Site-directed mutagenesis}

To confirm the interaction of PKCa with pErk1/2, three different PKCa mutants [MAPK docking motif $\left(R^{159,161} \mathrm{G}\right)$ double mutant, kinase dead PKCa (KD-PKCa) and catalytically active PKCa $(\mathrm{CA}-\mathrm{PKC} \alpha$ )] were prepared along with wild type PKC $\alpha$ (Supplementary Fig. S3A). MAPK docking motif in the regulatory and catalytic domains of PKCa was predicted and searched by using website http://elm.eu.org and based on the published reports (Bardwell et al., 2001; Yang et al., 1998). Arginine residues at 159 and 161 in the regulatory domain of PKC $\alpha$ were mutated to glycine $\left(R^{159,161} \mathrm{G}\right)$ by using QuikChange II site-- 
Table 1. Primers used for real-time PCR analyses

\begin{tabular}{lll}
\hline Gene & & Primer \\
\hline P21 ${ }^{\text {waf1 }}$ & Forward & $5^{\prime}$-CGACTGTGATGCGCTAATGG-3' \\
& Reverse & $5^{\prime}$-CCGTTTTCGACCCTGAGAG-3' \\
FH (fumarate hydratase) & Forward & $5^{\prime}$-CCATGTTGCTGTCACTGTCGGAGG-3' \\
& Reverse & $5^{\prime}$-CATACCCTATATGAGGATTGAGAG-3' \\
IDH1 (isocitrate dehydrogenase) & Forward & $5^{\prime}$-ACCAATCCCATTGCTTCCATTTTT-3' \\
& Reverse & $5^{\prime}$-TCAAGTTTTCTCCAAGTTTATCCA-3' \\
IDH2 (isocitrate dehydrogenase 2) & Forward & $5^{\prime}$-CAGGAGATCTTTGACAAGCAC-3' \\
& Reverse & $5^{\prime}$-ATGAGGTCTTGGTTCCCATC-3' \\
MDH2 (malate dehydrogenase 2) & Forward & $5^{\prime}$-GCTCTGCCACCCTCTCCATG-3' \\
& Reverse & $5^{\prime}$-TTTGCCGATGCCCAGGTTCTTCTC-3' \\
18S rRNA & Forward & $5^{\prime}$-GGAGAGGGAGCCTGAGAAAC-3' \\
& Reverse & $5^{\prime}$-TCGGGAGTGGGTAATTTGC-3' \\
\hline
\end{tabular}

directed mutagenesis kits (Stratagene, USA) according to the manufacturer's recommendations. Wild type PKCa-HA plasmid in pHACE vector was used as a template and the specific mutation was confirmed by DNA sequencing.

\section{RNA-sequencing analysis}

The integrity of RNAs isolated from HDF senescent cells treated with TPA for $8 \mathrm{~h}$ and $24 \mathrm{~h}$, or DMSO control, was confirmed by bioanalyzer with an Agilent RNA 6000 Pico Kit (Agilent, USA), and then mRNA sequencing library was prepared by TruSeq stranded mRNA sample preparation kit (Illumina, USA) according to manufacturer's instruction. The functional category analyses of the differentially expressed genes (DEGs) were performed by DAVID (http://david.abcc.ncifcrf.gov), Enrichr (http://amp.pharm. mssm.edu/Enrichr/) or PANTHER (http://pantherdb.org/) tools. The DEGs were selected with the significance level of $p<0.001$ or false discovery rate $<0.05$ after multiple testing corrections for the compared conditions, TPA $8 \mathrm{~h}$ vs. $0 \mathrm{~h}$ (DMSO control) and TPA $24 \mathrm{~h}$ vs. $0 \mathrm{~h}$ (DMSO control).

\section{Real-time PCR analysis}

Total cellular RNAs were extracted with RNAiso Plus (TaKaRa Bio, Japan), and cDNAs were synthesized with RNA $1.0 \mu \mathrm{g}$ and reverse transcription kit (Invitrogen). The cDNAs were amplified with specific primers and SYBR Green PCR Master Mix (Applied Biosystems) under the conditions by using CFX96 Touch $^{\text {TM }}$ Real-Time PCR Detection System (Bio Rad, USA): Initial activation at $95^{\circ} \mathrm{C}$ for $15 \mathrm{~min}$, followed by 40 cycles at $95^{\circ} \mathrm{C}$ for $20 \mathrm{~s}$ and $60^{\circ} \mathrm{C}$ for $40 \mathrm{~s}$. Primers used for assays were listed in Table 1. To quantify transcriptional activity, 18S rRNA expression was measured as a control.

\section{Determination of ATP content}

Total amount of ATP in HDF cells were measured by using ATP determination kit produced by Molecular Probes (Invitrogen) based on the described method (Candas et al., 2013) with slight modification. Young and old HDF cells were incubated for $24 \mathrm{~h}$ before trypsinization, and the cells harvested by centrifugation at $4,800 \times g$ for 5 min at $4^{\circ} \mathrm{C}$ were resuspended in $1 \%$ trichloroacetic acid/4 mM EDTA solution. ATP extraction was performed by incubating the cells for $10 \mathrm{~min}$ on ice and then centrifuged at $12,000 \times g$ for $10 \mathrm{~min}$ at $4^{\circ} \mathrm{C}$ to harvest supernatant for ATP measurement. Concentration of protein in the pel- lets were measured by vigorous vortexing in RIPA buffer and discarding the debris after centrifugation for $20 \mathrm{~min}$. Level of ATP luminescence was measured by using BioTek Synergy 2 microplate reader and the contents of ATP were calculated based on the standard curves obtained from known amounts of ATP. Concentration of ATP was normalized by amount of protein isolated from used cells.

\section{Statistical analysis}

All data were presented as means \pm S.D and analyzed by 1-way ANOVA for comparison between multiple groups using SPSS. Probability values less than 0.05 were considered as statistically significant.

\section{RESULTS}

$P K C \alpha$ is required for $p E r k 1 / 2$ translocation to the HDF cell nucleus in response to TPA stimulation

To assess the TPA-mediated activation and re-distribution of PKC isoforms, senescent HDF cells were fractionated and subjected to immunoblot (IB) analysis. TPA treatment significantly increased PKCa and $\mathrm{pErk1/2}$ translocation to the cell nucleus (Fig. 1A), whereas PKC $\beta 1$ localization did not change despite the increase of $\mathrm{pErk} 1 / 2$ in the cell nuclear fraction (Supplementary Figs. S1A-1C). To evaluate whether pErk1/2 translocation was physically coupled with PKCa localization, HDF cells with or without TPA treatment were subjected to coimmunoprecipitation (IP) and IB analyses with anti-pErk1/2 and anti-PKC $\alpha$ antibodies. Figure 1B shows increased interaction between PKC $\alpha$ and pErk1/2 after TPA treatment despite the same quantity of PKCa being present in the $10 \%$ inputs of the DMSO- and TPA-treated cells. These results suggest the cotranslocation of PKC $\alpha$ with $\mathrm{pErk1/2}$. Indeed, the knockdown of $\mathrm{PKC} \alpha$ expression significantly reduced $\mathrm{pErk} 1 / 2$ translocation after TPA treatment (Fig. 1C, $p<0.001$ ), indicating a role for $\mathrm{PKC} \alpha$ in $\mathrm{pErk} 1 / 2$ translocation. Conversely, no interaction between $\mathrm{pErk} 1 / 2$ and PKC $\beta 1$ was observed by in vivo IP assay (Supplementary Fig. S1D). Based on our evidence that TPA treatment reduces tethering of SA-pErk1/2 to PEA-15 in the cytoplasm of old HDF cells (Lee et al., 2015), interactions between pErk1/2, PEA-15, and PKC $\alpha$ were evaluated by IP and IB analyses. The results showed that in old, but not young, cells, pErk1/2 was bound to PEA-15 prior to TPA stimulation. How- 

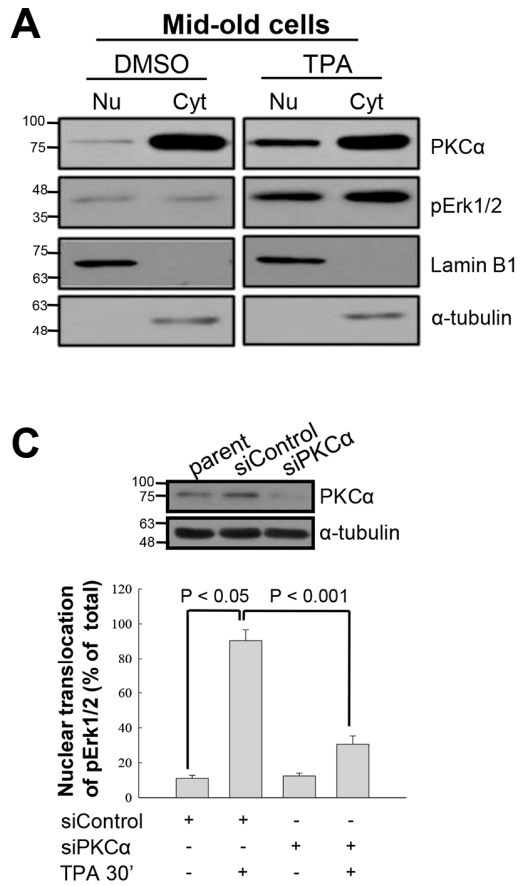

E

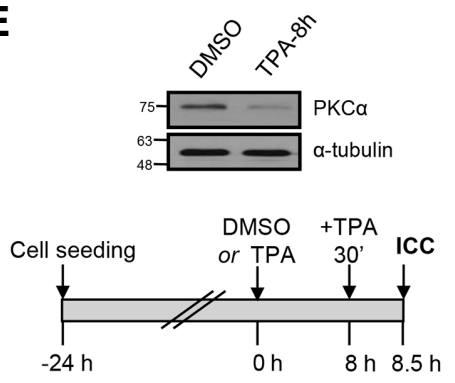

B

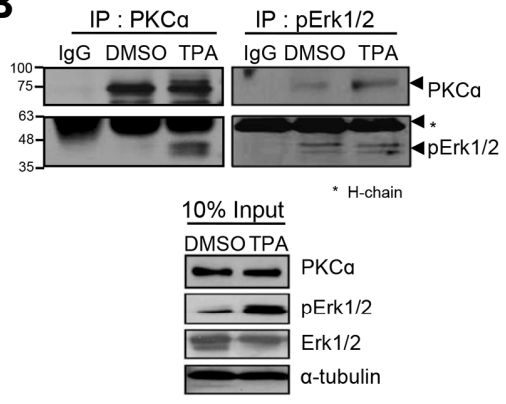

D

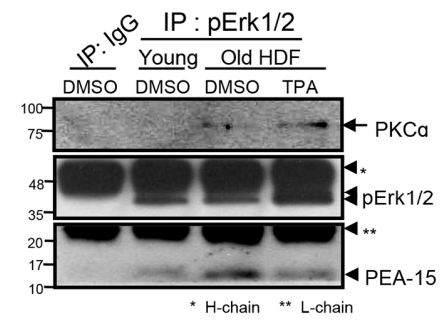

$\mathbf{F}$

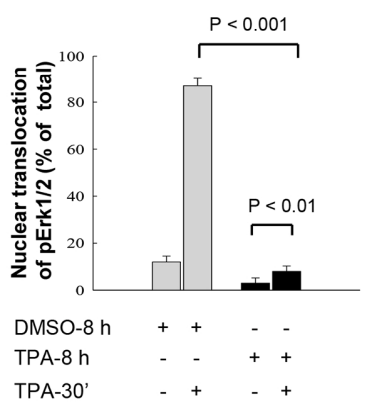

Fig. 1. Expression of PKCa is required for translocation of pErk1/2 to nuclei of HDF cells in response to TPA. (A) HDF mid-old cells were treated with either DMSO $(0.01 \%)$ or TPA (50 $\mathrm{ng} / \mathrm{ml}$ ) for $30 \mathrm{~min}$ and the nuclear and cytoplasmic fractions of the cells were subjected to immunoblot analysis using anti-PKC $\alpha$ and antipErk1/2 antibodies. TPA treatment significantly increased the amounts of PKC $\alpha$ and pErk1/2 in the particulate fraction, compared with DMSO treatment. Lamin B1 and $\alpha$-tubulin expressions were employed as markers of nuclear and cytoplasmic fractions. (B) To evaluate whether pErk $1 / 2$ translocation to nuclei was accompanied with PKC $\alpha$ or not, co-immunoprecipitation (co-IP) analysis was performed with anti-pErk1/2 and anti-PKC $\alpha$ antibodies. As shown in the 10\% input, TPA increased $p E r k 1 / 2$ level, however, the protein expression of $P K C \alpha$ was independent of TPA treatment for 30 min (lower panel). Based on the co-IP data (upper panels), the amount of pErk1/2 immunoprecipitates was the same in the DMSO and TPA treatment cells, whereas interaction of $\mathrm{PKC} \alpha$ with $\mathrm{pErk} 1 / 2$ was clearly increased by TPA treatment. (C) To test whether $\mathrm{PKC} \alpha$ protein is required for the TPA-induced pErk1/2 translocation or not, knockdown of $\mathrm{PKC} \alpha$ expression was employed by transfection of siRNAs with or without TPA treatment for 30 $\mathrm{min}$, and the degree of pErk1/2 translocation was examined by immunocytochemistry (ICC). TPA treatment markedly increased translocation of $p E r k 1 / 2$ into nuclei $(p<0.05)$, however, the effect of TPA was clearly reduced by knockdown of PKC $\alpha$ expression ( $p<0.001$ ), indicating the requirement of $\mathrm{PKC} \alpha$ protein for the $\mathrm{pErk} 1 / 2$ translocation to nuclei. Senescent HDF cells with $\mathrm{pErk} 1 / 2$ in nuclei were counted and pre-

sented by \% of total cells (lower panel). Upper panel shows knockdown of PKC $\alpha$ expression after transfection of siRNAs. The same experiments were performed more than 3 times and counted more than 100 old cells per each experiment. (D) To evaluate the interactions among PKC $\alpha, p E r k 1 / 2$ and PEA-15 in HDF old cells, IP was performed with anti-pErk1/2 antibody. The constitutive interaction between SA-pErk1/2 and PEA-15 in old cells was significantly higher than that of the young cells, whereas it was reduced after TPA treatment up to the young cell level, in contrast to the increased interaction between $p E r k 1 / 2$ and PKC $\alpha$. The data suggest the mutually exclusive interaction of SA-pErk1/2 with either PEA-15 or PKC $\alpha$ upon TPA treatment in senescent cells. IP with IgG reveals specific binding of pErk1/2 to PKC $\alpha$ or PEA-15. (E, F) To further confirm the effect of PKC $\alpha$ protein on the TPA-induced nuclear translocation of $p E r k 1 / 2$, senescent HDF cells were treated again with TPA for $30 \mathrm{~min}$ after TPA pretreatment for $8 \mathrm{~h}$, and then ICC with anti-pErk1/2 antibody was performed. The $8 \mathrm{~h}$-TPA pretreatment significantly reduced PKC $\alpha$ expression [upper panel in (E)] along with the significant reduction of the 30 min-TPA effect on the pErk1/2 translocation as compared with that of the $8 \mathrm{~h}$-DMSO pretreatment $[p<0.001,(F)]$. However, the cells still maintained TPA effect on the $p E r k 1 / 2$ translocation $[p<0.01$, $(F)]$.

ever, pErk1/2 interacted with PKC $\alpha$ upon TPA treatment (Fig. 1D). When temporal changes in the nuclear translocation of PKC $\alpha$ and pErk1/2 were evaluated by immunocytochemical assay (ICC), translocation was observed to be significant at 30 min and maintained until $8 \mathrm{~h}$ after TPA treatment compared with that of control cells treated with DMSO (Supplementary Fig. S2B). Translocation was accompanied by a change in cell shape from large and flat to small and sharp (Supplementary Fig. S2A). The protein expression of PKC $\alpha$, but not Erk1/2 and PEA-15, was almost undetectable at $8 \mathrm{~h}$ after stimulation (Supplementary Fig. $\mathrm{S} 2 \mathrm{C}$ ). When PKCa expression was depleted by TPA pretreatment for $8 \mathrm{~h}$ (Fig. 1E), nuclear translocation of pErk1/2 stimulated by TPA re-stimulation for $30 \mathrm{~min}$ was significantly reduced (Fig.
$1 \mathrm{~F}, \mathrm{p}<0.001,2^{\text {nd }}$ and $4^{\text {th }}$ bars), although some response was still observed (Fig. $1 F, p<0.01$ vs. DMSO $8.5 \mathrm{~h}$ ). These data strongly suggest the regulation of $\mathrm{pErk} 1 / 2$ translocation by PKC $\alpha$ upon the TPA stimulation of senescent cells.

PKCß1, but not PKC $\alpha$, regulates PEA-15 phosphorylation at $S^{104}$ in response to TPA, causing PEA-15 to dissociate from pErk1/2 in old HDF cells

Because there is no information on which PKC isoform(s) phosphorylate(s) PEA-15 at residue $\mathrm{S}^{104}$, either PKC $\alpha$ or PKC $\beta 1$ expression was knocked down using specific small interfering (si) RNAs, and PEA-15ps ${ }^{104}$ expression was determined by IB analysis. Transfection of old HDF cells with 
A

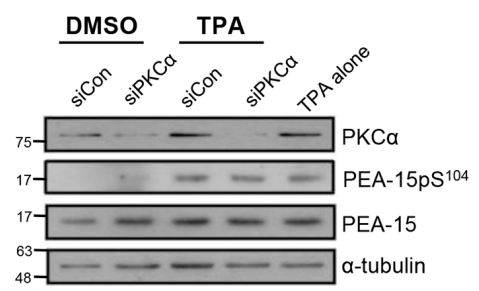

B

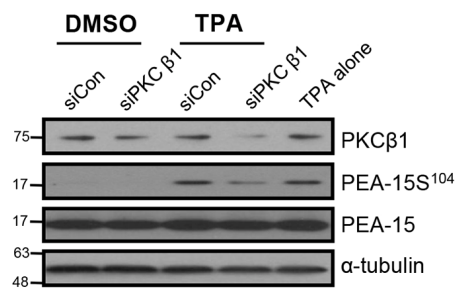

C

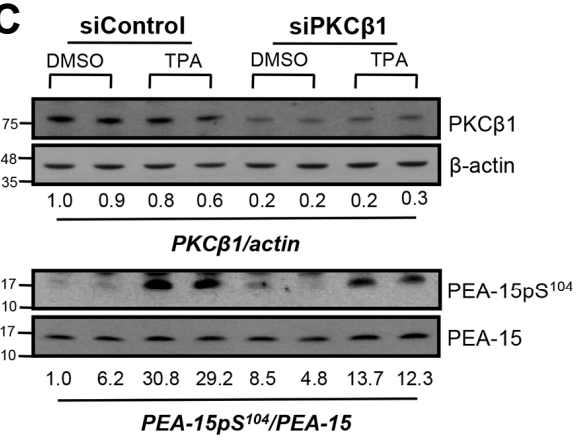

D

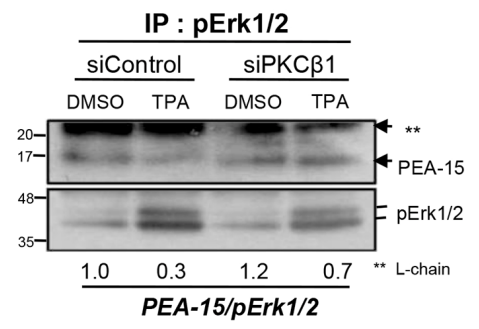

$\mathbf{E}$

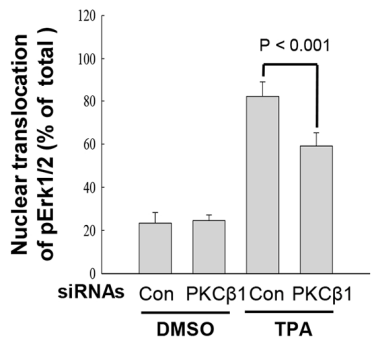

$\mathbf{F}$

In vitro kinase-immunoblot assay

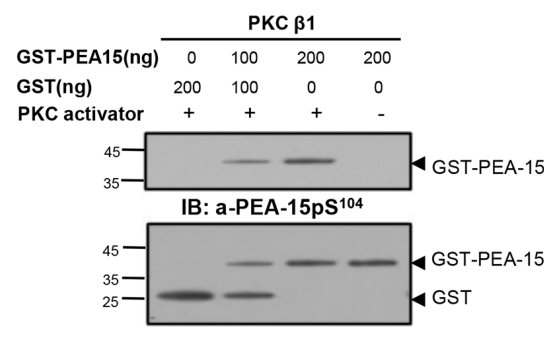

Fig. 2. $P K C \beta 1$, not $P K C \alpha$, regulates phosphorylation of PEA-15 at $S^{104}$ in response to TPA, which dissociates pErk1/2 from PEA15 in HDF old cells. (A) To explore PKC isozymes which regulate PEA-15pS ${ }^{104}$, knockdown of PKCa was performed by transfection of senescent HDF cells with siRNAs to PKC $\alpha$ (siPKC $\alpha$ ) for $48 \mathrm{~h}$, and the cells were treated with DMSO or TPA for 30 min before IB analysis. The scrambled siRNAs (siCon) and $\alpha$-tubulin were used as controls for transfection and immunoblot analyses, respectively. Note persistence of PEA-15pS ${ }^{104}$ after TPA treatment in the siPKC $\alpha$ transfected cells similar to the TPA alone treated cells, indicating not so significant effect of PKC $\alpha$ on the regulation of PEA-15 phosphorylation. (B) To investigate effect of PKC $\beta 1$ on the TPA-mediated phosphorylation of PEA-15 at $S^{104}$, senescent HDF cells were transfected with siRNAs to PKC $\beta 1$ (siPKC $\beta 1$ ) for $48 \mathrm{~h}$ and then treated with TPA for $30 \mathrm{~min}$. The cell lysates were analyzed by IB with anti-PKC $\beta 1$, antiPEA-15pS ${ }^{104}$ or anti-PEA-15 antibodies. Note downregulation of PEA-15 phosphorylation after knockdown of PKC $\beta 1$ compared with that of the control. siCon and $\alpha$-tubulin were used as controls for transfection and immunoblot analyses, respectively. (C) To confirm the role of $P K C \beta 1$ in the regulation of PEA-15 phosphorylation, degradation of $P K C \beta 1$ was manipulated by transfection with siPKC $\beta 1$ for $48 \mathrm{~h}$ and then changes of PEA-15pS ${ }^{104}$ by TPA treatment for $30 \mathrm{~min}$ were measured based on the amount of PEA-15 expression. PKC $\beta 1$ expression was downregulated up to $20-30 \%$ than that of the siCon, based on actin expression (PKC $\beta 1 /$ actin; 0.2-0.3 vs.1.0), whereas TPA-induced PEA15 phosphorylation was reduced more than $50 \%$ by knockdown of PKC $\beta 1$ (PEA-15ps ${ }^{104} /$ PEA-15 ratio; $12.3-13.7$ vs. 30). (D) To evaluate whether knockdown of PKC 31 regulates interaction of $p E r k 1 / 2$ with PEA-15 or not, HDF old cells transfected with either siCon or siPKC 31 were treated with TPA for $30 \mathrm{~min}$ and then the cell lysates were subjected to IP-IB analysis. TPA treatment significantly reduced interaction of pErk1/2 with PEA-15 (0.3 vs. 1.0), however, it was recovered in part by transfection of siPKC $\beta 1$ than that of the siCon (0.7 vs. 0.3$)$. The data strongly suggest in vivo regulation of PEA-15 phosphorylation at $S^{104}$ residue by PKC $\beta 1$ in response to TPA. (E) To explore whether PKC $\beta 1$ induced PEA-15pS ${ }^{104}$ regulates nuclear translocation of pErk1/2 in response to TPA, more than 500 old cells were captured and the cells with pErk1/2 in nuclei were counted under the microscope. Bars represent the means \pm SD after 3 independent experiments. TPA-induced nuclear translocation of $p E r k 1 / 2$ was significantly reduced by transfection with siPKC $\beta 1$ compared with that of the siControl $(p<0.001)$, indicating that PKC $\beta 1$ is active in the regulation of pErk1/2 translocation to nuclei via PEA-15 phosphorylation at $S^{104}$ residue. $(F)$ To evaluate activity of PKC isozyme regulating PEA-15pS ${ }^{104}$, in vitro kinase assay was performed for 30 min at $30^{\circ} \mathrm{C}$ with GST-PEA-15 as a substrate and PKC $\beta 1$ with or without PKC activator. PEA-15 phosphorylation at $S^{104}$ residue was determined by immunoblot analysis with anti-PEA-15pS ${ }^{104}$ antibody. PKC $\beta 1$ activity was increased in the substrate concentration dependent manner in the presence of PKC activator. Hybridization of the reaction mixture with anti-GST antibody showed proteins loaded into each reaction.

siPKC $\alpha$ failed to reduce PEA-15pS ${ }^{104}$ expression after TPA treatment (Fig. 2A), whereas transfection with siPKC $\beta 1$ significantly downregulated PEA-15pS ${ }^{104}$ (Fig. 2B). These data suggest that $P K C \beta 1$ is an in vivo kinase for PEA-15pS ${ }^{104}$. Furthermore, when PKC $\beta 1$ expression was reduced by siPKC $\beta 1$ transfection (from 0.6-1.0 to 0.2-0.3 seen with siControl), the TPAstimulated PEA-15pS ${ }^{104}$ level was also reduced to $12.3-13.7$ compared with 29.2-30.8 in the siControl-treated cells, indicating a reduction in TPA-induced PEA-15pS ${ }^{104}$ following PKC $\beta 1$ knockdown (Fig. 2C). Moreover, IP-IB analysis showed that
PKC $\beta 1$ knockdown also failed to dissociate PEA-15 from binding to pErk $1 / 2$ after TPA treatment (0.7 vs. 0.3) (Fig. 2D). Thus, PKC $\beta 1$ probably contributes to PEA-15 phosphorylation on residue $\mathrm{S}^{104}$ after TPA treatment. It should be noted that TPAinduced pErk $1 / 2$ translocation was inhibited $25 \%$ by PKC $\beta 1$ knockdown (Fig. 2E), indicating a partial influence of PKC $\beta 1$ on the TPA-induced nuclear translocation of pErk1/2 after dissociation from PEA-15ps ${ }^{104}$. Moreover, in vitro kinase and IB analyses using a recombinant protein substrate and purified enzyme revealed that PKC $\beta 1$ catalyzes GST-PEA-15 phosphory- 
A

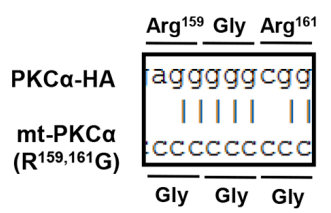

B

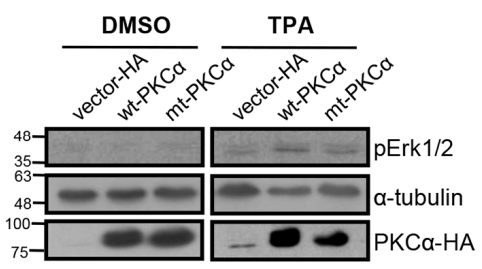

D

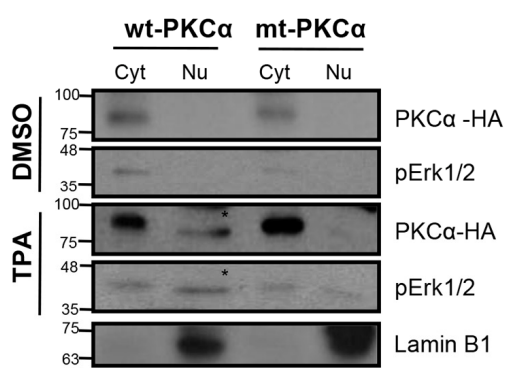

C

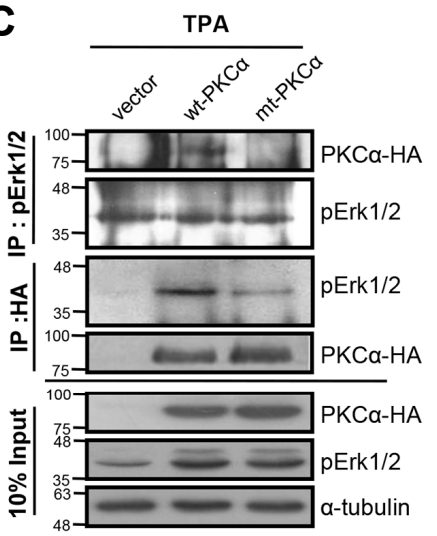

$\mathbf{F}$

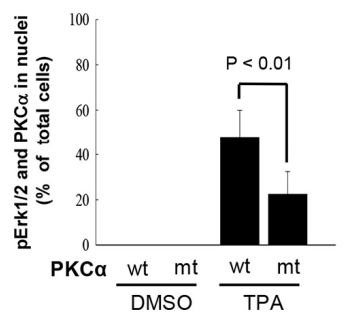

E

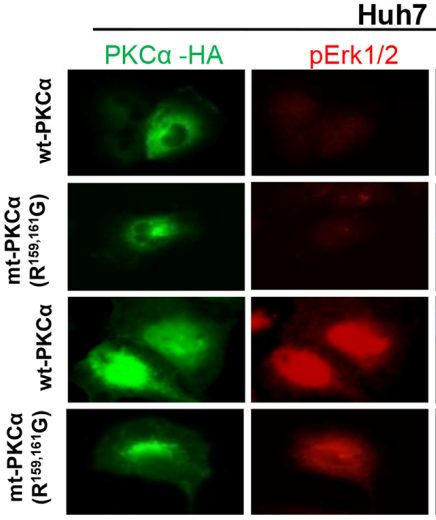

Huh7 Cells

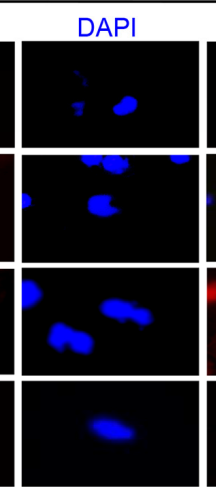

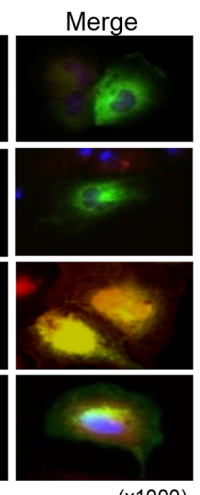

Fig. 3. Both regulatory and catalytic domains of wt-PKC $\alpha$ are required for $\mathrm{pErk} 1 / 2$ translocation to nuclei in response to TPA. (A) To evaluate the effect of MAPK docking motif of PKC $\alpha$ on the pErk $1 / 2$ translocation, site-directed mutagenesis was employed; therefore, $R^{159}$ and $R^{161}$ residues were double-mutated to glycine, and the $\mathrm{mt}\left(\mathrm{R}^{159,161} \mathrm{G}\right)-\mathrm{PKC} \alpha$ was confirmed by DNA sequencing. (B) IB analysis. To evaluate in vivo effect of $\mathrm{PKC} \alpha$ on Erk $1 / 2$ phosphorylation, Huh7 cells were transiently transfected with wt-PKC $\alpha$ (PKC $\alpha-\mathrm{HA})$, $\mathrm{mt}\left(\mathrm{R}^{159,161} \mathrm{G}\right)-\mathrm{PKC} \alpha$ or vector control (pcDNA3$\mathrm{HA}$ ) for $48 \mathrm{~h}$, and then treated with either TPA or DMSO for 30 min before subjected to IB analysis. In vivo expressions of wt-PKC $\alpha$ and $\mathrm{mt}\left(\mathrm{R}^{159,161} \mathrm{G}\right)-\mathrm{PKC} \alpha$ were confirmed by anti-HA antibody. Note mutation-independent phosphorylation of Erk1/2 by overexpressed PKC $\alpha$ in response to TPA. (C) Co-IP and IB analyses. To explore the effect of PKC $\alpha$ mutation at $\mathrm{R}^{159,161}$ residue on the interaction with pErk1/2, co-IP with anti-pErk1/2 and anti-HA antibodies were performed. Note significant reduction of $\mathrm{pErk} 1 / 2$ interaction with $\mathrm{mt}-\mathrm{PKC} \alpha$ than that of the wt-PKC $\alpha$ after TPA treatment, indicating the role of $\mathrm{R}^{159,161}$ residue in the interaction with $p E r k 1 / 2$. (D) IB analyses showing co-translocation of wt-PKC $\alpha$, but not mt$\mathrm{PKC} \alpha$, with $\mathrm{pErk} 1 / 2$ into nuclear fractions. Huh7 cells transfected with either wt-PKC $\alpha$ or mt-PKCa were treated with DMSO $(0.01 \%)$ or TPA $(50 \mathrm{ng} / \mathrm{ml})$ for $30 \mathrm{~min}$ and then the fractions were subjected to IB analyses. Note the expressions of $\mathrm{PKC} \alpha$ and $\mathrm{pErk} 1 / 2$ in the nuclear fraction of wt-PKC $\alpha$, but not mt-PKC $\alpha$, transfected cells. (E) Confocal microscope findings revealing co-translocation of $\mathrm{pErk} 1 / 2$ with wt-PKC $\alpha$ in Huh7 cells. Note partially reduced translocation of $\mathrm{pErk} 1 / 2$ in the mtPKC $\alpha$ expresser compared with the wt-PKC $\alpha$ after TPA treatment. However, there is no significant translocation by DMSO treatment. $(F)$ To confirm the effect of $m t\left(R^{159,161} G\right)-P K C \alpha$ on the TPA-induced $\mathrm{pErk} 1 / 2$ translocation,

ICC was performed with anti-pErk1/2 and anti-PKC $\alpha$ antibodies and counted the cells with nuclear pErk1/2 and PKC $\alpha$; TPA-induced pErk1/2 translocation was significantly reduced by overexpression of $m t\left(R^{159,161} G\right)-P K C \alpha$ compared with that of the wt-PKC $\alpha(p<0.01)$. The data further support the role of regulatory domain of PKC $\alpha$ as a MAPK docking motif and the effect of their interaction on the nuclear translocation of $\mathrm{pErk1/2}$. Data represent means $\pm \mathrm{SD}$ after two independent experiments with duplicates.

lation on residue $\mathrm{S}^{104}$ in the presence of a PKC activator (Fig. $2 \mathrm{~F}$ ). These data further support PKC $\beta 1$ as the in vivo kinase phosphorylating PEA-15 on residue $\mathrm{S}^{104}$.

\section{Both regulatory and catalytic domains of wild-type PKCO are required for pErk1/2 translocation to the nucleus in senescent cells after TPA treatment}

The PKC $\alpha$ domains that interact with $\mathrm{pErk1/2}$, were investigated in Huh7 cells, and the potential MAPK docking motifs within the PKC $\alpha$ molecule were predicted by computer simulation. Using site-specific mutation analysis, PKC $\alpha$ mutant constructs $\operatorname{mt}\left(R^{159,161} G\right)-P K C \alpha$, kinase-dead $P K C \alpha$, constitutively active
PKC $\alpha$, and wild-type (wt) PKC $\alpha$ were prepared (Supplementary Fig. S3A). All mutations were confirmed by DNA sequencing analysis (Fig. 3A). Confocal microscopy showed that each transfected construct significantly increased PKC $\alpha$ fluorescence in the particulate fraction of TPA-treated Huh7 cells; however, Erk1/2 activation and translocation only occurred in cells transfected with wt-PKC $\alpha$. These data suggested that $\mathrm{PKC} \alpha$ kinase activity and the regulatory domain were required for $\mathrm{pErk} 1 / 2$ translocation. This possibility was confirmed by ICC and reciprocal IP analyses (Supplementary Fig. S3B; Figs. 3B and $3 \mathrm{C}$ ). The importance of the pErk1/2 docking motif within the PKC $\alpha$ regulatory domain was further evaluated using cell 
A

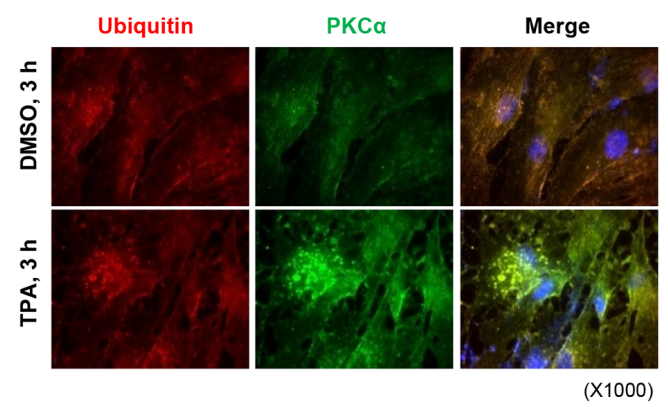

B

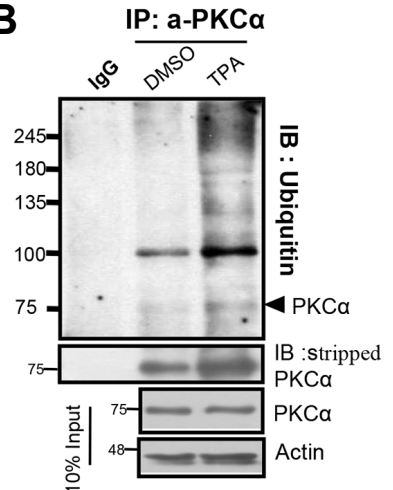

C

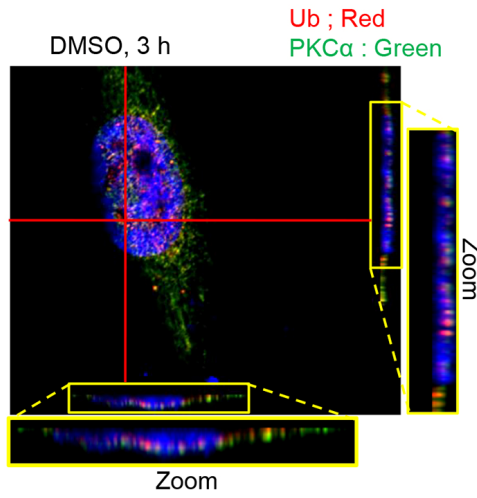

E

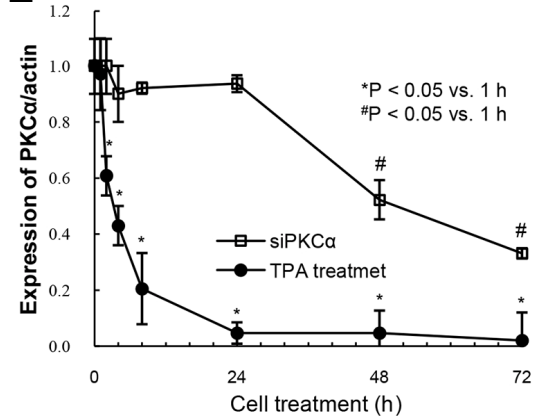

D

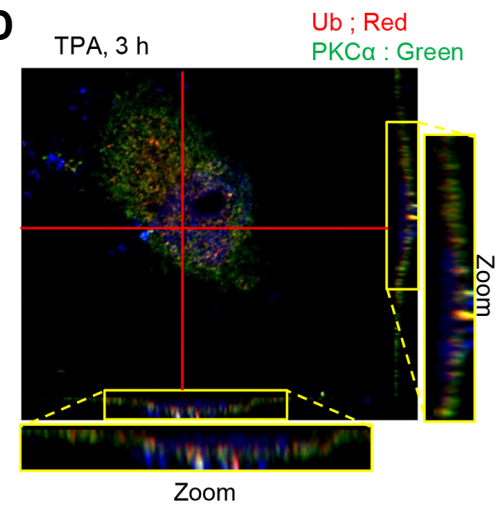

$\mathbf{F}$

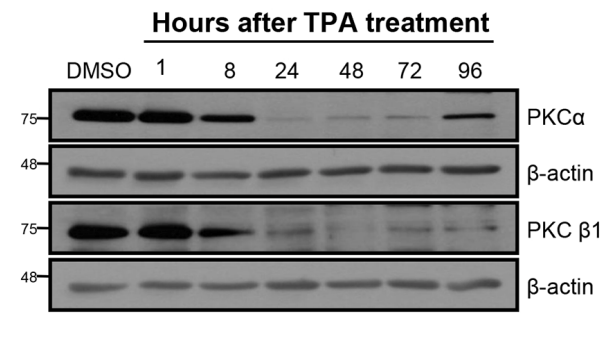

Fig. 4. TPA rapidly degrades PKCa in nuclei of senescent cells, whereas its regeneration is so delayed. To examine the fate of PKC $\alpha$ after TPA stimulation in nuclei of senescent cells, ICC and IP-IB analyses were performed in the presence and absence of proteasome inhibitor, MG132. (A) TPA treatment significantly increased fluorescence of PKC $\alpha$ in the nuclei of senescent HDF cells in 3 $\mathrm{h}$, indicating nuclear translocation of $\mathrm{PKC} \alpha$ in the cells. In addition, the fluorescence derived from ubiquitin and PKC $\alpha$ was co-localized in the nuclei of the cells. (B) IP with anti-PKC $\alpha$ antibody and IB with anti-ubiquitin antibody showed polyubiquitination of PKC $\alpha$ after TPA + MG132 treatment as compared with that of the DMSO + MG132 treatment (upper panel) along with the slight accumulation of $\mathrm{PKC} \alpha$ protein in the TPA + MG132 treated cells than the control (middle panel). The 10\% input shows equal loading of the proteins for IP analysis (lower panels). (C) Confocal microscope findings revealing the separate location of $\mathrm{PKC} \alpha$ and ubiquitin molecules in the nuclei of HDF cells in 3 $\mathrm{h}$ of DMSO treatment. However, TPA treatment induced co-translocation of PKC $\alpha$ and ubiquitin molecules in nuclei of the cells treated with TPA for $3 h(D)$, when scrutinized by Z-section. Note the red $(\mathrm{Ub})$ and the green $(\mathrm{PKC} \alpha)$ dots in the cells treated with DMSO, whereas the dots were co-localized upon treatment of HDF cells with TPA. (E) To investigate the kinetic changes of PKC $\alpha$ degradation by either TPA or siRNAs, old HDF cells were harvested at the indicated times and then the degree of PKC $\alpha$ expression was measured by IB analyses. Expressions of PKC $\alpha$ relative

to that of the $0 \mathrm{~h}$ were calculated, and then plotted against hours of cell treatment. PKC $\alpha$ expression was persistent until $24 \mathrm{~h}$ after siPKC $\alpha$ transfection, whereas it was significantly reduced in $2 \mathrm{~h}$ of TPA treatment. The rapid degradation of PKC $\alpha$ in response to TPA was presented as the means \pm SD of the 4 independent experiments and the kinetic changes of PKC $\alpha$ after siPKC $\alpha$ transfection was presented as the means \pm SD of 3 independent experiments. Note significant difference of the PKC $\alpha$ kinetics induced by TPA treatment and by siPKC $\alpha$ transfection. (F) Immunoblot analyses showing the degradation and regeneration of PKC isozymes after single treatment of old HDF cells with TPA. Note significant downregulation of PKC $\alpha$ and PKC $\beta 1$ in $8 \mathrm{~h}$ and the complete lost in $24 \mathrm{~h}$ until $72 \mathrm{~h}$. PKC $\alpha$ was regenerated in $96 \mathrm{~h}$ of TPA single treatment.

fractionation and IB analyses (Fig. 3D) and ICC after transfection of Huh7 cells with PKC $\alpha$ constructs (Fig. 3E). Both wt$\mathrm{PKC} \alpha$ and $\mathrm{mt}\left(\mathrm{R}^{159,161} \mathrm{G}\right)-\mathrm{PKC} \alpha$ activated Erk1/2 following TPA stimulation; however, pErk1/2 and PKC $\alpha$ nuclear translocation were reduced by $60 \%$ in the $\mathrm{mt}\left(\mathrm{R}^{159,161} \mathrm{G}\right)-\mathrm{PKC} \alpha$ expressing cells as compared with that in wt-PKC $\alpha$ expressing cells (Fig. 3F). These results indicate that TPA-induced Ekr1/2 phosphorylation was regulated by the PKC $\alpha$ catalytic domain, whereas $\mathrm{pErk1/2}$ nuclear translocation required a PKC $\alpha$ regulatory domain containing wild-type $\mathrm{R}^{159 \text { and } 161}$ residues.
TPA rapidly degrades $P K C \alpha$ in senescent cell nuclei, and its regeneration is a delayed response

To characterize TPA-mediated PKC $\alpha$ downregulation in the senescent cell nuclei, old HDF cells were subjected to ICC using an anti-ubiquitin antibody. Under immunofluorescence microscope, ubiquitin and PKC $\alpha$ were found to be co-localized in the nuclei of TPA-treated cells (Fig. 4A) together with an increase in $\mathrm{PKC} \alpha$-ubiquitin ladders following cell treatment with MG132 (Fig. 4B). To further evaluate ubiquitin-mediated PKC $\alpha$ degradation in the cell nucleus, a Z-stack analysis was performed and viewed under confocal microscope. The presence 


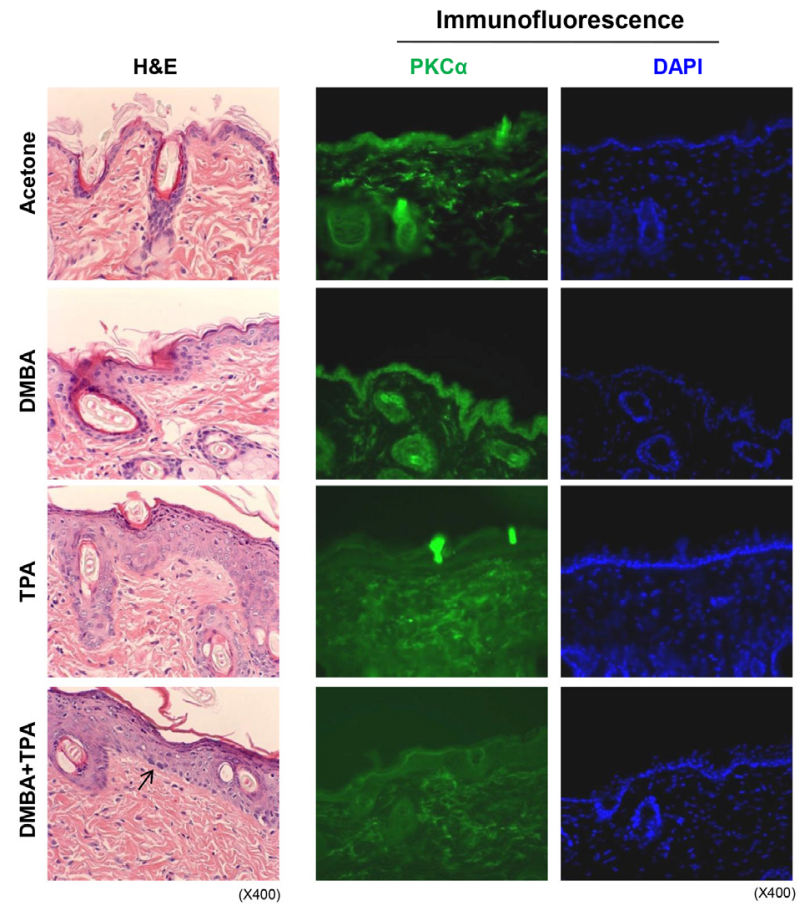

Fig. 5. Degradation of PKC $\alpha$ expression accompanies with epidermal proliferation in CD1 mice in response to repetitive TPA treatment. In order to evaluate in vivo effect of TPA on the loss of PKC $\alpha$ expression and subsequent regulation of cell proliferation, immunohistochemistry and immunofluorescence analyses were employed in CD1 male mice ( 9 week-old) by using topical treatment with TPA for 2 weeks (twice/week) with or without DMBA pretreatment on the back skin once. Mice were sacrificed in 3 days of the final treatment with TPA. (A) H\&E staining ( $x 400$ ): Acetone treated mouse skin shows one or two layered epidermis. DMBA single treated skin shows two or three layered epidermis. TPA treated mouse skin shows marked acanthosis of epidermis and hair follicles. DMBA + TPA treated mouse skin shows marked acanthosis with hyperchromatic nuclei in the basal cell layer (arrow). (B) Immunofluorescence staining: PKC $\alpha$ is expressed in the epidermis and hair follicles of the acetone and the DMBA alone treated CD1 mice, whereas it was focally expressed in dermis of the groups. On the other hand, PKC $\alpha$ expression was significantly lost in the epidermis and hair follicles of the TPA treated and the DMBA + TPA treated mice skin. The fluorescence was rather nonspecifically diffuse in the dermis. DAPI shows nuclei present in the epidermis and hair follicles.

of ubiquitin and PKC $\alpha$ was further confirmed by merged fluorescence in the TPA-treated cell nuclei (Fig. 4D) but not in the DMSO-treated cell nuclei (Fig. 4C). Therefore, we tested the kinetics of PKC $\alpha$ degradation in old HDF cells using either transfection with siPKC $\alpha$ or TPA treatment. As shown in Fig. 4E, the loss of PKC $\alpha$ expression was much faster after TPA treatment than after siPKC $\alpha$ transfection. This observation agrees with our previous report that old HDF cell proliferation is higher after TPA treatment than after siRNA transfection (Lee et al., 2015). Moreover, in these cells, the temporal changes in PKC $\alpha$ expression after TPA treatment for $8 \mathrm{~h}$ and $24 \mathrm{~h}$ (Fig. 4F) align with the morphologic and cytoskeletal changes observed after 8 $\mathrm{h}$ and $20 \mathrm{~h}$ of TPA treatment (Fig. 3 in Kwak et al., 2004). The partial regeneration of $\mathrm{PKC} \alpha$ expression was observed at $96 \mathrm{~h}$ after a single treatment with TPA (Fig. 4F), indicating that PKC $\alpha$ regeneration is a delayed event as opposed to its very rapid degradation after initial TPA treatment. Collectively, these data strongly imply that $\mathrm{PKC} \alpha$ downregulation allows senescent cells to undergo a senescence process reversal.

PKC $\alpha$ degradation accompanies epidermal proliferation in $C D 1$ mice in response to repetitive TPA treatment

To confirm our hypothesis that TPA-induced degradation of $\mathrm{PKC} \alpha$ might stimulate proliferation and induce senescence process reversal in senescent cells and that similar events may also occur during the promotion stage of carcinogenesis, CD-1 mice were subjected to DMBA initiation and subsequent topical applications of TPA (twice/week) for 2 weeks. Excised skin tissues were examined by immunohistochemistry and IF analyses (Fig. 5). After vehicle treatment and a DMBA single treatment, no proliferation was observed in the basal layer of the skin epidermis by hematoxylin and eosin staining. However, repetitive TPA treatment induced acanthosis of the epidermis and hair follicles independent of DMBA initiation. Treatment with DMBA plus TPA induced the formation of abnormal cells with hyperchromatic nuclei (arrow) in the basal layer. Labeling with an anti-PKC $\alpha$ antibody followed by immunofluorescent staining of serial tissue sections revealed a loss of PKC $\alpha$ expression along with increased cell proliferation in the epidermis of TPAtreated mice. The loss of PKC $\alpha$ expression in the epidermis persisted for 20 weeks with repetitive treatment (data not shown). These in vivo data strongly support our assumption that the loss of PKC $\alpha$ expression initiates cell proliferation independent of carcinogen-induced initiation, implying that the senescent cells that contain DNA segments with chromatin alterations reinforcing senescence (Rodier et al., 2011) might be more susceptible to both carcinogenesis and reverse senescence phenomenon.

RNA sequence analyses support the senescence reversal program observed in old HDF cells after TPA treatment

To confirm the senescence reversal in old HDF cells in response to TPA, RNA sequence analysis was performed using mRNAs isolated from old HDF cells treated with TPA for $8 \mathrm{~h}$ and $24 \mathrm{~h}$, and cells treated with DMSO as a control. The most variable 1,000 genes were subjected to unsupervised clustering, and the differentially expressed genes (DEGs) between the 2 selected conditions were analyzed using Cuffdiff software, with significance thresholds of $p<0.001$ or a false discovery rate $<0.05$ after multiple corrections. A heat map was generated by hierarchical clustering of the up- and down-regulated DEG values of 222 out of the 1000 genes analyzed (Supplementary Fig. S4A). The changes in gene expression observed at TPA-8 $\mathrm{h}$ and TPA-24 $\mathrm{h}$ treatment relative to DMSO treatment $(0 \mathrm{~h})$ are presented as a gene ontology analysis in Tables 2 and 3 , respectively. All data strongly supported the occurrence of cell cycle progression, along with the morphological and cytoskeletal changes in senescent cells linked with reduced focal adhesion to extracellular matrix. Thus, the flat and large senescent cells began to look like younger cells. The change was clearer on the heat map generated by the hierarchical clustering of 53 DEGs (Supplementary Fig. S4B).

TPA-induced senescence reversal reduces senescence marker expression and increases mitochondrial metabolism and oxidative phosphorylation

To assess whether the TPA-induced changes in senescent cell morphology and gene expression were accompanied by 
Table 2. Gene ontology analyses of the significantly up-regulated genes in the HDF old cells treated with TPA for $8 \mathrm{~h}$ and $24 \mathrm{~h}$, based on the DMSO control, obtained by RNA sequencing.

\begin{tabular}{|c|c|c|c|c|}
\hline & & Term & Count & $P$-value \\
\hline TPA $8 \mathrm{~h}$ vs. $0 \mathrm{~h}$ & GOTERM_BP_FAT & GO:0042127 regulation of cell proliferation & 13 & 0.002404 \\
\hline in old HDFs & & GO:0008284 positive regulation of cell proliferation & 8 & 0.011902 \\
\hline \multirow[t]{19}{*}{ (up-regulation) } & & GO:0051726 regulation of cell cycle & 6 & 0.048291 \\
\hline & & GO:0040007 growth & 5 & 0.02407 \\
\hline & & GO:0010628 positive regulation of gene expression & 8 & 0.058907 \\
\hline & & GO:0045893 positive regulation of transcription, DNA-dependent & 7 & 0.066019 \\
\hline & & GO:0031328 positive regulation of cellular biosynthetic process & 12 & 0.002474 \\
\hline & & GO:0043069 negative regulation of programmed cell death & 10 & 2.86E-04 \\
\hline & & GO:0006916 anti-apoptosis & 7 & 0.001457 \\
\hline & & GO:0006469 negative regulation of protein kinase activity & 7 & 1.31E-05 \\
\hline & & GO:0043407 negative regulation of MAP kinase activity & 5 & 6.07E-05 \\
\hline & & GO:0006954 inflammatory response & 8 & 0.003291 \\
\hline & & GO:0006955 immune response & 11 & 0.007953 \\
\hline & GOTERM_MF_FAT & GO:0005125 cytokine activity & 10 & 2.54E-04 \\
\hline & & GO:0008083 growth factor activity & 7 & 0.055948 \\
\hline & & GO:0004175 endopeptidase activity & 8 & 0.639307 \\
\hline & GOTERM_CC_FAT & GO:0005615 extracellular space & 17 & 1.17E-06 \\
\hline & & GO:0044421 extracellular region part & 19 & 5.18E-06 \\
\hline & & GO:0005576 extracellular region & 27 & 2.46E-05 \\
\hline & KEGG_PATHWAY & hsa04060:Cytokine-cytokine receptor interaction & 9 & 2.51E-04 \\
\hline & & hsa04630:Jak-STAT signaling pathway & 6 & 0.003358 \\
\hline TPA $24 \mathrm{~h}$ vs. $0 \mathrm{~h}$ & GOTERM_BP_FAT & GO:0006874 cellular calcium ion homeostasis & 4 & 0.021492 \\
\hline in old HDFs & & GO:0008544 epidermis development & 4 & 0.021799 \\
\hline \multirow[t]{7}{*}{ (up-regulation) } & & GO:0006875 cellular metal ion homeostasis & 4 & 0.025678 \\
\hline & & GO:0030005 cellular di-, tri-valent inorganic cation homeostasis & 4 & 0.037309 \\
\hline & GOTERM_MF_FAT & GO:0005125 cytokine activity & 4 & 0.028158 \\
\hline & & GO:0004857 enzyme inhibitor activity & 6 & 0.002098 \\
\hline & & GO:0030414 peptidase inhibitor activity & 5 & 0.001745 \\
\hline & GOTERM_CC_FAT & GO:0005576 extracellular region & 24 & 1.65E-07 \\
\hline & KEGG_PATHWAY & hsa04630:Jak-STAT signaling pathway & 3 & 0.054783 \\
\hline
\end{tabular}

changes in cell physiology and metabolism, p21 ${ }^{\text {WAF1 }}$ expression was measured by real-time PCR analysis after TPA treatment. As shown in Fig. 6A, the level was significantly reduced $24 \mathrm{~h}$ after TPA treatment. In addition, the mitochondrial citric acid cycle-regulating enzymes IDH, IDH2, $\mathrm{FH}$, and $\mathrm{MDH} 2$ were all markedly increased in the old HDF cells after $24 \mathrm{~h}$ of TPA stimulation (Fig. 6B). Finally, mitochondrial oxidative phosphorylation was also significantly increased along with ATP generation after TPA treatment but not after DMSO treatment (Fig. 6C). These data indicate that reverse senescence includes not only changes in gene expression and cell physiology, but also in energy metabolism in response to TPA stimulation.

\section{DISCUSSION}

It is well established that PKC is a receptor for tumor-promoting phorbol esters (Kikkawa et al., 1983) that translocates from the cell cytosol to particulate fractions upon stimulation (Buchner, 1995). However, the fate and the role of PKC isozyme nuclear translocation during cell senescence and carcinogenesis remain largely unknown. In the present study, we investigated the differential functions of PKC $\alpha$ and PKC $\beta 1$, with a focused on the senescence reversal in old HDF cells. Our results confirmed that the loss of PKC $\alpha$ in epithelial cells is also observed in in vivo carcinogenesis. In fact, TPA-activated PKC $\beta 1$ dissociates SA-pErk1/2 from PEA-15 by phosphorylating PEA-15 at $S^{104}$, which releases $p E r k 1 / 2$ to interact with the regulatory domain of wt-PKC $\alpha$ prior to nuclear translocation. PKC $\alpha$ is rapidly ubiquitinated and degraded in the cell nucleus prior to $\mathrm{pErk} 1 / 2$ inactivation; thus, freeing $\mathrm{pErk} 1 / 2$ to participate in the cell proliferation program (Fig. 7). As previously reported, there is no difference in the level of PKC $\alpha$ and PKC $\beta 1$ expression between the young and senescent HDF cells; however, kinase activity is significantly greater in the senescent cells than in the young 
Common Pathway in Reversal of Senescence and Tumor Promotion

Yun Yeong Lee et al.

Table 3. Gene ontology analyses of the significantly down-regulated genes in the HDF old cells treated with TPA for $8 \mathrm{~h}$ and $24 \mathrm{~h}$, based on the DMSO control, obtained by RNA sequencing.

\begin{tabular}{|c|c|c|c|c|}
\hline & & Term & Count & $P$-value \\
\hline TPA $8 \mathrm{~h}$ vs. $0 \mathrm{~h}$ & GOTERM_BP_FAT & GO:0048705 skeletal system morphogenesis & 3 & 0.010597 \\
\hline in old HDFs & & GO:0006493 protein amino acid O-linked glycosylation & 2 & 0.034557 \\
\hline \multirow[t]{9}{*}{ (down-regulation) } & & GO:0010324 membrane invagination & 3 & 0.037542 \\
\hline & & GO:0006897 endocytosis & 3 & 0.037542 \\
\hline & GOTERM_MF_FAT & GO:0030247 polysaccharide binding & 4 & 0.001861 \\
\hline & & GO:0001871 pattern binding & 4 & 0.001861 \\
\hline & & GO:0008201 heparin binding & 3 & 0.011865 \\
\hline & & GO:0030246 carbohydrate binding & 4 & 0.018571 \\
\hline & & GO:0005539 glycosaminoglycan binding & 3 & 0.021203 \\
\hline & GOTERM_CC_FAT & GO:0044421 extracellular region part & 5 & 0.041449 \\
\hline & BIOCARTA_Pathway & $\begin{array}{l}\text { h_LDLpathway:Low-density lipoprotein (LDL) pathway during } \\
\text { atherogenesis }\end{array}$ & 2 & 0.004175 \\
\hline \multirow{18}{*}{$\begin{array}{l}\text { TPA } 24 \mathrm{~h} \text { vs. } 0 \mathrm{~h} \\
\text { in old HDFs } \\
\text { (down-regulation) }\end{array}$} & GOTERM_BP_FAT & GO:0006873 cellular ion homeostasis & 6 & 0.008503 \\
\hline & & GO:0055082 cellular chemical homeostasis & 6 & 0.009074 \\
\hline & & GO:0007010 cytoskeleton organization & 6 & 0.015732 \\
\hline & & GO:0007155 cell adhesion & 7 & 0.030208 \\
\hline & & GO:0022610 biological adhesion & 7 & 0.030391 \\
\hline & GOTERM_MF_FAT & GO:0005198 structural molecule activity & 8 & 0.003887 \\
\hline & & GO:0005509 calcium ion binding & 9 & 0.00835 \\
\hline & & GO:0005516 calmodulin binding & 4 & 0.010365 \\
\hline & & GO:0046873 metal ion transmembrane transporter activity & 5 & 0.021059 \\
\hline & & GO:0015267 channel activity & 5 & 0.043363 \\
\hline & & GO:0022803 passive transmembrane transporter activity & 5 & 0.043687 \\
\hline & GOTERM_CC_FAT & GO:0031012 extracellular matrix & 6 & 0.006373 \\
\hline & & GO:0005626 insoluble fraction & 9 & 0.00715 \\
\hline & & GO:0000267 cell fraction & 10 & 0.010283 \\
\hline & & GO:0005624 membrane fraction & 8 & 0.019534 \\
\hline & & GO:0005911 cell-cell junction & 4 & 0.027414 \\
\hline & & GO:0042383 sarcolemma & 3 & 0.022226 \\
\hline & KEGG_PATHWAY & hsa04514:Cell adhesion molecules (CAMs) & 4 & 0.008906 \\
\hline
\end{tabular}

cells (Kim and Lim, 2009). Also, there is a substantial accumulation of ROS within the senescent cells relative to the young cells (Kim et al., 2003). From a mechanistic viewpoint, the contributions of the nuclear ubiquitination of PKC $\alpha$ to the regulation of senescence reversal may be explained in part by our previous report that the activated and abundant concentrations of PKCs might induce Erk1/2 phosphorylation and subsequent activation of SP1 at residue $\mathrm{S}^{59}$, increasing p21 $21^{\text {WAF1 }}$ transcription during the senescence process (Fig 7A). Indeed, tethering pErk $1 / 2$ to PEA-15 in the cytoplasm maintains senescence until the degradation of PKCa following TPA treatment (Lee et al., 2015). Treating HDF cells once with TPA significantly downregulates PKC $\alpha$ concentrations between 8 and $96 \mathrm{~h}$ after exposure (Figs. 4E and 4F). This process indicates that TPAinduced nuclear translocation of PKC $\alpha$ and SA-pErk1/2 and subsequent PKC $\alpha$ degradation in the nucleus might be essential for the reversal of senescence, thus representing a barrier that must be overcome for malignant transformation of mam- malian cells (Campisi, 2005; Wright and Shay, 2001). It is established that HDF cells, which were derived from the foreskin, do not express the $\mathrm{p} 16^{\text {INK4a }}$ gene and that the absence of the p16 INK4a/pRB signaling pathway allows senescence reversal in HDF cells (Beausejour et al., 2003). Thus, cytoplasmic sequestration of $\mathrm{pErk} 1 / 2$ by PEA-15 might represent an important mechanism for maintaining cellular senescence and resistance to mitogenic signals in senescent HDF cells (Lee et al., 2015). The PKC $\beta 1$-mediated release of $p E r k 1 / 2$ from PEA-15 and subsequent PKCa degradation shown in the present study might be a prerequisite for senescence reversal and epidermal proliferation in vivo (Fig. 7B). The in vivo and in vitro phosphorylation of PEA-15 at $S^{104}$ by PKC $\beta 1$ was confirmed by knockdown of PKC $\beta 1$ expression with siRNA transfection and kinase assay-IB analysis (Fig. 2). Although PKC $\alpha$ also phosphorylates GST-PEA-15 at $S^{104}$ residue in vitro (data not shown), the discrepancy between results might be because of the direct phosphorylation of GST by PKCa (Rodriguez et al., 2005) and the 
A

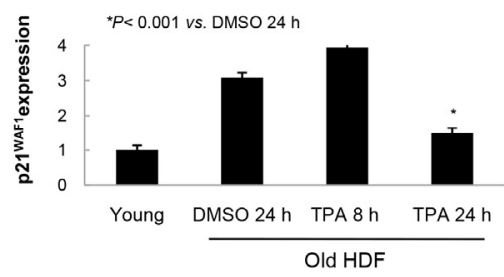

B

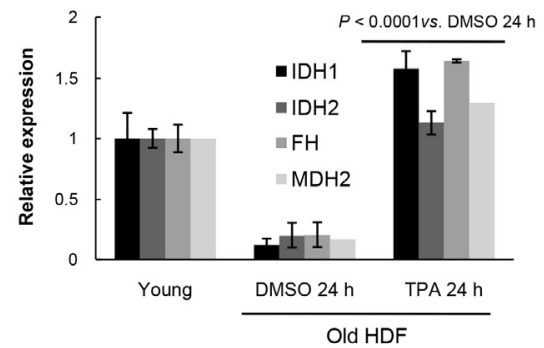

C

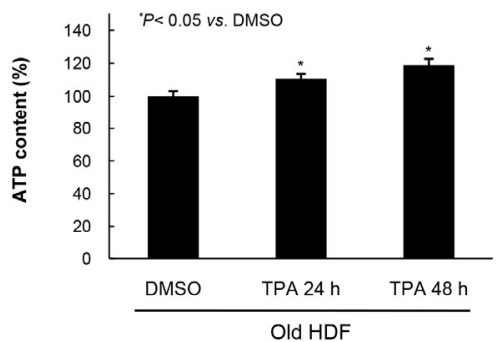

Fig. 6. TPA-induced reversal of senescence changes expressions of molecular markers and mitochondrial respiration. (A) Real time PCR analysis showing the significant inhibition of p21 WAF1 expression in HDF old cells in $24 \mathrm{~h}$ of TPA treatment. (B) Marked increase of the mitochondrial enzymes regulating TCA cycle in $24 \mathrm{~h}$ of TPA treatment in HDF old cells. Note significant increases of the isocitrate dehyrogenase 1 and 2 (IDH, IDH2), mitochondrial fumarate hydratase (FH), and mitochondrial isoform 1 precursor of malate dehydrogenase (MDH2). (C) Increase of ATP level in HDF old cells in response to TPA treatment compared with that of the DMSO treatment.

A

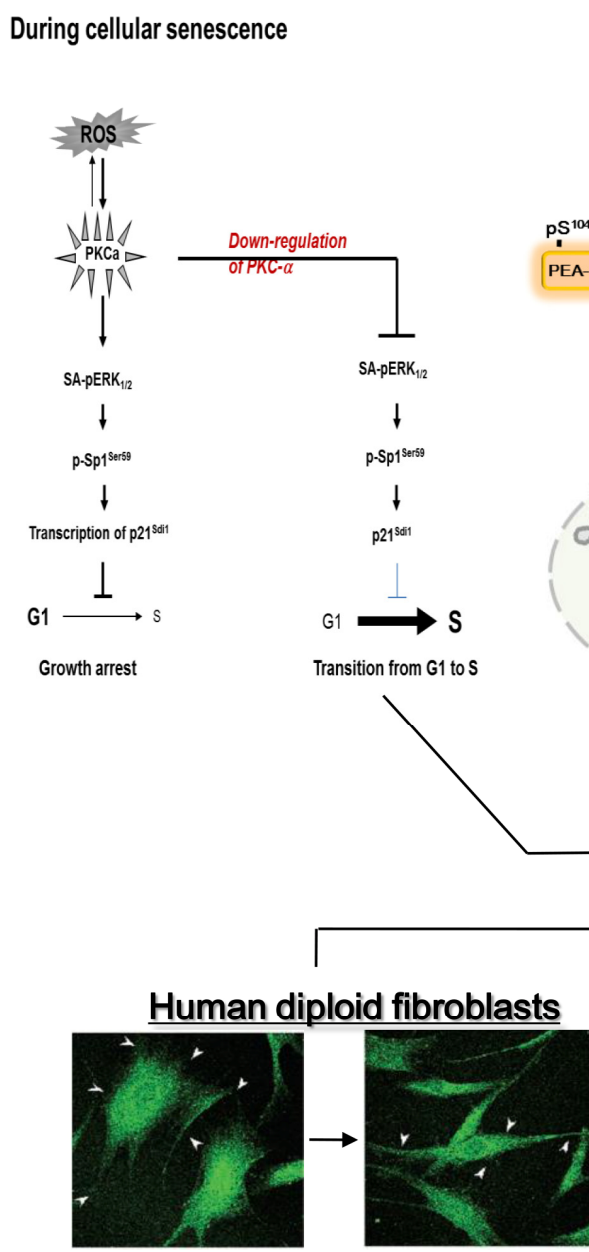

Reversal of senescence

\section{B TPA-mediated reverse senescence and epidermal proliferation}

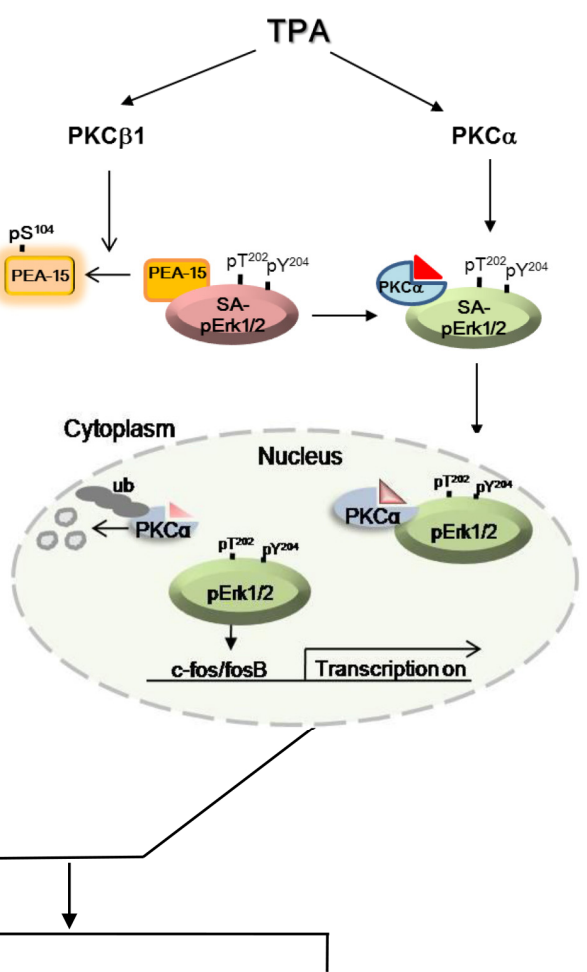

Mouse skin epidermis

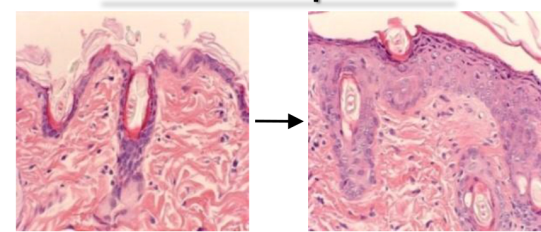

Epidermal proliferation
Fig. 7. $\mathrm{PKC} \alpha$ and $\mathrm{PKC} \beta 1$ plays differentially in the nuclear translocation of pErk1/2 upon TPA treatment which regulates reversal of senescence phenotypes. (A) During replicative senescence, highly accumulated ROS triggers activation of PKC isozymes without their protein expression, which leads to the induction of $221^{\text {WAF1 }}$ expression through the activations of Erk1/2 and Sp1 transcription factor. However, knockdown of PKC $\alpha$ isoform by transfection with siRNAs reverses senescence program and rather induces cell proliferation after overcome the $\mathrm{G} 1 / \mathrm{S}$ arrest. The diagram has been reported by the authors (Kim and Lim, 2009). (B) PKC $\beta 1$ activated by TPA regulates in vivo phosphorylation of PEA-15 at $\mathrm{S}^{104}$ residue, which triggers dissociation of SA-pErk1/2 (Senescence Associated-pErk1/2) sequestered in cytoplasm from PEA-15. TPAstimulated PKC $\alpha$ binds to SA-pErk1/2 released from PEA-15pS ${ }^{104}$ and then translocated to nuclei of the cells. In the nucleus, $p E r k 1 / 2$ is released from $\mathrm{PKC} \alpha$ after its ubiquitination, which triggers a series of gene expression that participates in reversal of the large and flat senescence cells to the actively growing young cells. TPA-induced series of gene expression can be shared by tumor promoting response in skin, which resulted in epidermal proliferation. 
higher affinity of PKC $\beta 1$ for PEA-15 $\mathrm{S}^{104}$ than for PKC $\alpha$ (Nishikawa et al., 1997). Despite the translocation of activated PKC isozymes into various cell particulate fractions, the present results clearly indicate that translocated $\mathrm{PKC} \alpha$ molecules are degraded in the old HDF cell nuclei upon TPA treatment, triggering further reactions that reverse senescence. This notion is well supported by our previous reports demonstrating that knockdown of PKCa expression (Kim and Lim, 2009) or treatment with TPA significantly induces the proliferation of old HDF cells.

Based on our transfection analyses, the PKC $\alpha$ catalytic domain is sufficient for Erk1/2 activation in response to TPA (Supplementary Fig. S3B). However, TPA-induced pErk1/2 translocation requires the wt-PKC $\alpha$ MAPK interaction domain (Figs. $3 D-3 F$ ), indicating that PKC $\alpha$ functions in $p E r k 1 / 2$ nuclear translocation and phosphorylation. Indeed, PKC $\alpha, P K C \beta 1$, and PEA-15 have independent roles in facilitating the nuclear translocation of SA-pErk1/2, which induces senescence reversal upon TPA stimulation. The basal activity of PKC $\alpha$ and PKC $\beta 1$ is much higher in senescent cells than in young cells despite there being no difference in the levels of protein expression (Kim and Lim, 2009), with conditions maintained in a steady state in the senescent cells. We speculate that PKC isozyme stimulation by TPA and PKC $\alpha$ degradation in senescent cells may represent events that prime the cells for senescence reversal through $\mathrm{pErk} 1 / 2$ activation in senescent cell nuclei. Thus, the delayed regeneration of PKC $\alpha$ after TPA treatment (Fig. 4F) might provide an environment to stimulate cell proliferation, facilitate old cells to overcome an active senescence program, and undergo malignant transformation upon carcinogen initiation along with epidermal proliferation (Fig. 5). Indeed, the reversal of cellular senescence induced by TPA was well supported by the significant recovery of mitochondrial metabolism and ATP generation after $24 \mathrm{~h}$ of TPA treatment as compared with that in the DMSO control (Fig. 6).

Note: Supplementary information is available on the Molecules and Cells website (www.molcells.org).

\section{ACKNOWLEDGMENTS}

Authors greatly appreciate careful reading of this manuscript by Prof. Woon Ki Paik. This work was supported by the National Research Foundation (NRF) grant (No. 2013R1A2A2A 01005056) funded by the Korean government (MSIP), and the grants of the Korea Health technology R\&D Project, Ministry of Health \& Welfare, Republic of Korea (A121725) and the National R\&D Program for Cancer Control, Ministry for Health and Welfare, Republic of Korea (131280).

\section{REFERENCES}

Abel, E.L., Angel, J.M., Kiguchi, K., and DiGiovanni, J. (2009). Multistage chemical carcinogenesis in mouse skin: fundamentals and applications. Nat. Protoc. 4, 1350-1362.

Alessandrini, A., Crews, C.M., and Erikson, R.L. (1992). Phorbol ester stimulates a protein-tyrosine/threonine kinase that phosphorylates and activates the Erk-1 gene product. Proc. Natl. Acad. Sci. USA 89, 8200-8204.

Alexandropoulos, K., Qureshi, S.A., and Foster, D.A. (1993). HaRas functions downstream from protein kinase $C$ in v-Fpsinduced gene expression mediated by TPA response elements. Oncogene 8, 803-807.

Araujo, H., Danziger, N., Cordier, J., Glowinski, J., and Chneiweiss, H. (1993). Characterization of PEA-15, a major substrate for protein kinase C in astrocytes. J. Biol. Chem. 268, 5911-5920.

Ashendel, C.L. (1985). The phorbol ester receptor: a phospholipidregulated protein kinase. Biochim. Biophys. Acta 822, 219-242.
Bardwell, A.J., Flatauer, L.J., Matsukuma, K., Thorner, J., and Bardwell, L. (2001). A conserved docking site in MEKs mediates high-affinity binding to MAP kinases and cooperates with a scaffold protein to enhance signal transmission. J. Biol. Chem. 276, 10374-10386.

Beausejour, C.M., Krtolica, A., Galimi, F., Narita, M., Lowe, S.W., Yaswen, P., and Campisi, J. (2003). Reversal of human cellular senescence: roles of the p53 and p16 pathways. EMBO J. 22, 4212-4222.

Buchner, K. (1995). Protein kinase $C$ in the transduction of signals toward and within the cell nucleus. Eur. J. Biochem. 228, 211-221.

Campisi, J. (2005). Senescent cells, tumor suppression, and organismal aging: good citizens, bad neighbors. Cell 120, 513522.

Camps, M., Nichols, A., Gillieron, C., Antonsson, B., Muda, M., Chabert, C., Boschert, U., and Arkinstall, S. (1998). Catalytic activation of the phosphatase MKP-3 by ERK2 mitogen-activated protein kinase. Science 280, 1262-1265.

Candas, D., Fan, M., Nantajit, D., Vaughan, A.T., Murley, J.S., Woloschak, G.E., Grdina, D.J., and Li, J.J. (2013). CyclinB1/Cdk1 phosphorylates mitochondrial antioxidant MnSOD in cell adaptive response to radiation stress. J. Mol. Cell Biol. 5, 166-175.

Chang, L., and Karin, M. (2001). Mammalian MAP kinase signalling cascades. Nature 410, 37-40.

Chen, R.H., Sarnecki, C., and Blenis, J. (1992). Nuclear localization and regulation of erk- and rsk-encoded protein kinases. Mol. Cell Biol. 12, 915-927.

Clemens, M.J., Trayner, I., and Menaya, J. (1992). The role of protein kinase $\mathrm{C}$ isoenzymes in the regulation of cell proliferation and differentiation. J. Cell Sci. 103, 881-887.

Collado, M., Gil, J., Efeyan, A., Guerra, C., Schuhmacher, A.J., Barradas, M., Benguria, A., Zaballos, A., Flores, J.M., Barbacid, M., et al. (2005). Tumour biology: senescence in premalignant tumours. Nature $436,642$.

Cruzalegui, F.H., Cano, E., and Treisman, R. (1999). ERK activation induces phosphorylation of Elk-1 at multiple S/T-P motifs to high stoichiometry. Oncogene 18, 7948-7957.

Devanand, P., Kim, S.I., Choi, Y.W., Sheen, S.S., Yim, H., Ryu, M.S. Kim, S.J., Kim, W.J., and Lim, I.K. (2014). Inhibition of bladder cancer invasion by Sp1-mediated BTG2 expression via inhibition of DNA methyltransferase 1. FEBS J. 281, 5581-5601.

Jaken, S. (1990). Protein kinase C and tumor promoters. Curr. Opin Cell Biol. 2 192-197.

Kazi, J.U., and Soh, J.W. (2008). Induction of the nuclear protooncogene c-fos by the phorbol ester TPA and v-H-Ras. Mol. Cells 26, 462-467.

Kikkawa, U., Takai, Y., Tanaka, Y., Miyake, R., and Nishizuka, Y. (1983). Protein kinase C as a possible receptor protein of tumorpromoting phorbol esters. J. Biol. Chem. 258, 11442-11445.

Kim, H.S., and Lim, I.K. (2009). Phosphorylated extracellular signalregulated protein kinases 1 and 2 phosphorylate Sp1 on serine 59 and regulate cellular senescence via transcription of p21Sdi1/Cip1/Waf1. J. Biol. Chem. 284, 15475-15486.

Kim, H.S., Song, M.C., Kwak, I.H., Park, T.J., and Lim, I.K. (2003) Constitutive induction of $\mathrm{p}$-Erk $1 / 2$ accompanied by reduced activities of protein phosphatases 1 and $2 \mathrm{~A}$ and MKP3 due to reactive oxygen species during cellular senescence. J. Biol. Chem. 278, 37497-37510.

Krueger, J., Chou, F.L., Glading, A., Schaefer, E., and Ginsberg, M.H. (2005). Phosphorylation of phosphoprotein enriched in astrocytes (PEA-15) regulates extracellular signal-regulated kinase-dependent transcription and cell proliferation. Mol. Biol. Cell 16, 3552-3561.

Kwak, I.H., Kim, H.S., Choi, O.R., Ryu, M.S., and Lim, I.K. (2004). Nuclear accumulation of globular actin as a cellular senescence marker. Cancer Res. 64, 572-580.

Lee, Y.Y., Kim, H.S., and Lim, I.K. (2015). Downregulation of PEA15 reverses $\mathrm{G} 1$ arrest, and nuclear and chromatin changes of senescence phenotype via pErk1/2 translocation to nuclei. Cell. Signal. 27, 1102-1109.

Lim, I.K., Won Hong, K., Kwak, I.H., Yoon, G., and Park, S.C. (2000). Cytoplasmic retention of $\mathrm{p}$-Erk $1 / 2$ and nuclear accumulation of actin proteins during cellular senescence in human diploid fibroblasts. Mech. Ageing Dev. 119, 113-130.

Lu, Z., Liu, D., Hornia, A., Devonish, W., Pagano, M., and Foster, D.A. (1998). Activation of protein kinase $C$ triggers its 
ubiquitination and degradation. Mol. Cell Biol. 18, 839-845.

Menice, C.B., Hulvershorn, J., Adam, L.P., Wang, C.A., and Morgan, K.G. (1997). Calponin and mitogen-activated protein kinase signaling in differentiated vascular smooth muscle. J. Biol. Chem. 272, 25157-25161.

Nishikawa, K., Toker, A., Johannes, F.J., Songyang, Z., and Cantley, L.C. (1997). Determination of the specific substrate sequence motifs of protein kinase $\mathrm{C}$ isozymes. J. Biol. Chem. 272, 952-960.

Nishizuka, Y. (1992). Intracellular signaling by hydrolysis of phospholipids and activation of protein kinase C. Science 258 , 607-614.

Nishizuka, Y. (1995). Protein kinase $C$ and lipid signaling for sustained cellular responses. FASEB J. 9, 484-496.

Oliva, J.L., Caino, M.C., Senderowicz, A.M., and Kazanietz, M.G. (2008). S-Phase-specific activation of PKC alpha induces senescence in non-small cell lung cancer cells. J. Biol. Chem. 283, 5466-5476.

Pearson, G., Robinson, F., Beers Gibson, T., Xu, B.E., Karandikar, M., Berman, K., and Cobb, M.H. (2001). Mitogen-activated protein (MAP) kinase pathways: regulation and physiological functions. Endocr. Rev. 22, 153-183.

Renganathan, H., Vaidyanathan, H., Knapinska, A., and Ramos, J.W. (2005). Phosphorylation of PEA-15 switches its binding specificity from ERK/MAPK to FADD. Biochem. J. 390, 729-735.

Rodier, F., Munoz, D.P., Teachenor, R., Chu, V., Le, O., Bhaumik, D., Coppe, J.P., Campeau, E., Beausejour, C.M., Kim, S.H., et al. (2011). DNA-SCARS: distinct nuclear structures that sustain damage-induced senescence growth arrest and inflammatory cytokine secretion. J. Cell Sci. 124, 68-81.

Rodriguez, P., Mitton, B., and Kranias, E.G. (2005). Phosphorylation of glutathione-S-transferase by protein kinase $\mathrm{C}$-alpha implications for affinity-tag purification. Biotechnol Lett. 27, 1869-1873.

Thomas, S.M., DeMarco, M., D'Arcangelo, G., Halegoua, S., and Brugge, J.S. (1992). Ras is essential for nerve growth factor- and phorbol ester-induced tyrosine phosphorylation of MAP kinases. Cell 68, 1031-1040.

Vaidyanathan, H., Opoku-Ansah, J., Pastorino, S., Renganathan, H., Matter, M.L., and Ramos, J.W. (2007). ERK MAP kinase is targeted to RSK2 by the phosphoprotein PEA-15. Proc. Natl. Acad. Sci. USA 104, 19837-19842.

Vernier, M., Bourdeau, V., Gaumont-Leclerc, M.F., Moiseeva, O. Begin, V., Saad, F., Mes-Masson, A.M., and Ferbeyre, G. (2011). Regulation of E2Fs and senescence by PML nuclear bodies. Genes Dev. 25, 41-50.

Wen-Sheng, W., and Jun-Ming, H. (2005). Activation of protein kinase C alpha is required for TPA-triggered ERK (MAPK) signaling and growth inhibition of human hepatoma cell HepG2. J. Biomed. Sci. 12, 289-296.

Wright, W.E., and Shay, J.W. (2001). Cellular senescence as a tumor-protection mechanism: the essential role of counting. Curr. Opin. Genet. Dev. 11, 98-103.

Yang, S.H., Yates, P.R., Whitmarsh, A.J., Davis, R.J., and Sharrocks, A.D. (1998). The Elk-1 ETS-domain transcription factor contains a mitogen-activated protein kinase targeting motif. Mol. Cell Biol. 18, $710-720$ 